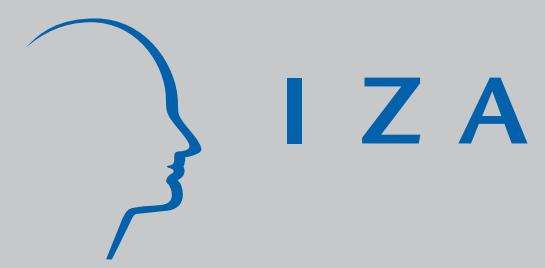

IZA DP No. 9722

Why Are Fewer Married Women Joining the Work Force in India? A Decomposition Analysis over Two Decades

Farzana Afridi

Taryn Dinkelman

Kanika Mahajan

February 2016 


\title{
Why Are Fewer Married Women Joining the Work Force in India? A Decomposition Analysis over Two Decades
}

\author{
Farzana Afridi \\ Indian Statistical Institute and IZA \\ Taryn Dinkelman \\ Dartmouth College and IZA \\ Kanika Mahajan \\ Indian Statistical Institute
}

\section{Discussion Paper No. 9722 \\ February 2016}

\author{
IZA \\ P.O. Box 7240 \\ 53072 Bonn \\ Germany \\ Phone: +49-228-3894-0 \\ Fax: +49-228-3894-180 \\ E-mail: iza@iza.org
}

Any opinions expressed here are those of the author(s) and not those of IZA. Research published in this series may include views on policy, but the institute itself takes no institutional policy positions. The IZA research network is committed to the IZA Guiding Principles of Research Integrity.

The Institute for the Study of Labor (IZA) in Bonn is a local and virtual international research center and a place of communication between science, politics and business. IZA is an independent nonprofit organization supported by Deutsche Post Foundation. The center is associated with the University of Bonn and offers a stimulating research environment through its international network, workshops and conferences, data service, project support, research visits and doctoral program. IZA engages in (i) original and internationally competitive research in all fields of labor economics, (ii) development of policy concepts, and (iii) dissemination of research results and concepts to the interested public.

IZA Discussion Papers often represent preliminary work and are circulated to encourage discussion. Citation of such a paper should account for its provisional character. A revised version may be available directly from the author. 


\section{ABSTRACT}

\section{Why Are Fewer Married Women Joining the Work Force in India? A Decomposition Analysis over Two Decades*}

Unlike the global trend, India has witnessed a secular decline in women's employment rates over the past few decades. We use parametric and semi-parametric decomposition techniques to show that changes in individual and household attributes fully account for the fall in women's labor force participation rate in 1987-1999 and account for half of the decline in this rate in 1999-2009. Our findings underscore increasing education levels amongst rural married women and the men in their households as the most prominent attributes contributing to this decline. We provide suggestive evidence that a rise in more educated women's returns to home production, relative to their returns in the labor market, may have adversely affected female labor force participation rates in India.

JEL Classification: J21, J22

Keywords: female labor force participation, decomposition analysis, education, India

Corresponding author:

Farzana Afridi

Indian Statistical Institute

7, S.J.S. Sansanwal Marg

New Delhi - 110016

India

E-mail: fafridi@isid.ac.in

* The authors thank the International Growth Center (IGC) - India Central, for financial support. Abhiroop Mukhopadhyay and Bharat Ramaswami provided valuable inputs. The authors are responsible for any remaining errors. 


\section{Introduction}

Women's participation in the labor market is often associated with better access to economic opportunities as well as greater decision-making power within the household. Globally, women are joining the labor force in larger and larger numbers - the gender gap in labor force participation declined by 6 percentage points between 1980 and 2009 (World Bank 2012).

But in contrast to the almost half of the world's female population that is working, only 32.6 percent of India's half a billion adult females report being part of the labor force (United Nations 2013 and India's National Sample Survey (NSS), respectively). This low rate of Indian women's labor market participation is puzzling for a country that has experienced rapid fertility transition (World Bank, various years) and broad increases in women's educational attainment (Census of India 2001 and 2011) along with substantial economic growth over the past two decades. ${ }^{1}$ Rather than facilitating entry of women into the labor force, these changes have been accompanied by a consistently low share of women working in urban areas (Klasen and Pieters 2015) and a real reduction in the share of women working in rural areas, between 1987 and 2009 (NSS, own calculations). ${ }^{2}$

Using nationally representative, cross-sectional data from three rounds of India's NSS, we undertake a decomposition analysis to examine whether changes in observed demographic and socio-economic characteristics of females can account for the fall in their labor force participation rate (LFPR) in and between the decades of 1987-1999 and 19992009. We show that the phenomenon of declining female LFPR over these two decades is concentrated among 25-65 year old, married women in rural India. Restricting our sample to this demographic group, we decompose changes in their employment rates into two components. The first component is attributable to shifts in demographic and socio-economic

\footnotetext{
${ }^{1}$ India's fertility rate declined from 4.12 in 1987 to 2.60 in 2009 (http://wdi.worldbank.org/table/2.17). Its GDP grew at an average rate of 5.85 percent during 1987-1999 and 7.15 percent in 1999-2009 (International Monetary Fund, various years).

270 percent of India's population continues to reside in rural areas (Census 2011).
} 
characteristics of women over time (for example educational upgrading and changes in household wealth). The second component is driven by changes in the probability of being employed for women with a given set of demographic and socio-economic attributes (e.g. to what extent are women with a given level of education working more or less over time?). Throughout the paper, we refer to the first element as the 'explained' proportion of the variation in LFPR over time, and the second element as the 'unexplained' proportion, since we do not directly observe the factors responsible for this component of change in women's LFPR.

What are the factors that could explain a decline in female LFPR over time? A view from economic history suggests that the stage of India's economic development might matter. At very low levels of GDP per capita, women must work for families to subsist. But as the per capita GDP rises, as has occurred in India in the past few decades, an income effect lowers women's work force participation. Continued economic growth along with higher incomes and higher wages for women in jobs with lower social stigma induces a substitution effect which outweighs the income effect and increases participation rates of women, leading to a U-shaped curve for female labor force participation (Goldin 1995). However, longitudinal analyses involving panel data models find mixed empirical evidence for this relationship (Lahoti and Swaminathan (2013) for India). Tam (2011) finds evidence in support of the hypothesis using data from 1950-1980 for 130 countries, but Gaddis and Klasen (2014) using data for additional years are not able to establish the 'U' shaped relationship between economic growth and women's work force participation. Moreover, the evidence on the relationship between higher educational attainment of women and their LFPR is ambiguous. While the greater supply of female high school graduates, coupled with an increased demand for clerical jobs, led to a more than 15 percentage point increase in the labor force participation rates of American women between 1930 and 1950 (Goldin 1995), in 
developing countries the picture is heterogeneous (Das and Desai 2003; Aromolaran 2004; Lincove 2008). Analyzing five Asian countries (Indonesia, Korea, Philippines, Sri Lanka and Thailand), Cameron, Dowling and Worswick (2001) find that female labor force participation rates respond differently to education across countries due to two potentially opposing effects: a wage effect and a bargaining power effect. Higher wages encourage women to join the workforce because the opportunity cost of time at home rises. However, if more education increases the relative bargaining power of women, and women prefer to not work, increasing levels of female education could lead to a fall in women's labor force participation. Moreover, even if female returns to education in the labor market rise, they may not rise fast enough to counteract the rise in the returns to education in the marriage market (Behrman et al. 1999) and in home production. For example, Lam and Duryea (1999) show that as Brazilian women get more schooling, total fertility falls and wages rise, but the share of women working does not increase. They hypothesize that in Brazil, home productivity effects are large enough to offset increases in market wages up to the first 8 years of education.

Several studies have offered specific explanations for the decline in female LFPR in rural India: increases in female enrollment in higher education, increases in real household incomes reducing the need for females to engage in wage work, and limited growth in employment opportunities for females (e.g. Neff, Sen and Kling 2012; Kannan and Raveendran 2012; Chowdhury 2011; Himanshu 2011). However, these studies are primarily descriptive in nature and do not quantify the relative importance of multiple factors that can explain the decline. Klasen and Pieters (2015) examine the stagnation in labor force participation of females in urban India. They attribute the stagnation to both demand and supply side factors. Using parametric decomposition analysis similar to ours, they find that on the supply side, rising household incomes and household heads' education reduced female 
LFPR in urban India while increases in female education raised participation. These two opposing effects have resulted in the stagnation of female LFPR in urban India.

Our paper is the first to quantify how much of the fall in female LFPR in rural India can be explained by the changing demographic and socio-economic characteristics of working age females between 1987 and 2009, and the contribution of each characteristic to the fall. ${ }^{3}$ Specifically, we highlight the increasing educational attainment of married women in India as an important factor contributing to the fall in female LFPR. ${ }^{4}$ Second, we show that the dramatic fall in women's LFPR is concentrated among married women in 25-65 age group rather than for all females in India. Third, in contrast to recent debates in India that focus only on the decade of 1999-2009, we underline the fact that the decline in women's LFPR is not a recent phenomenon but a long-term trend in rural India. We do this by comparing and contrasting the trends in women's LFPR in and between the decades of 19871999 and 1999-2009.

Our results suggest that the reasons behind the decline in rural women's work force participation vary across decades. Changes in observable demographic and socio-economic characteristics of married women completely explain the fall in their LFPR for the period 1987-1999, and explain up to 50 percent of the change in their LFPR between 1999 and 2009. The explanatory power of women's individual and household characteristics in the secular

\footnotetext{
${ }^{3}$ Eswaran et al. (2012) suggest that women's work force participation declines as household incomes increase and women participate more in 'status' related activities in India. This is consistent with India being on the initial downward-sloping part of Goldin's U-shaped curve of female LFP.

${ }^{4}$ Other concurrent studies which look at the determinants of female labor force participation in rural India are by Chatterjee, Murgai and Rama (2014), Sorsa et al. (2015), Kapsos, Silberman and Bourmpoula (2014) and Das et al. (2015). These studies also use the data from National Sample Surveys of India. Among these, the closest study to ours is by Kapsos, Silberman and Bourmpoula (2014). They undertake a decomposition exercise and state the explained component using coefficients from a pooled regression of female employment on characteristics for all the years under consideration. They do not analyze the contribution of each characteristic to the explained component. Chatterjee, Murgai and Rama (2014) control for local employment structures by including district level controls for persons employed in agriculture, non-farm self-employment, non-farm regular employment and casual work as a proportion of total population. They interpret these variables as capturing availability of jobs. The coefficients of these variables are positive and significant. However, these may also reflect supply side factors; all that we observe in the data is equilibrium employment.
} 
decline of their LFPR is large, although their importance appears to be falling over time. These results are robust to both parametric and non-parametric decomposition methods.

More importantly, we find that increases in both women's and men's education plays an instrumental role in explaining the decline in both decades. Between 1987 and 1999, we estimate that women's own education and that of the men in their household accounted for 87-95 percent of the overall decline in women's LFPR. In the 1999-2009 decade, they explain 25-37 percent of the total decline in women's LFPR. In contrast, the rise in household income accounts for no more than 16 percent of the decline in 1987-1999 while its effect is small and inconsistent in 1999-2009.

The stylized facts we document - that the fall in employment has occurred only among married women in rural India, at the same time that their participation in domestic work and their average level of education is increasing - suggests a possible reason for their declining LFPR: education increases female productivity in the home. If primary education provides basic skills to mothers in India, this may have a larger impact on their productivity in home tasks relative to their productivity in the market (e.g. Lam and Duryea 1999). Women may choose to invest in their homes, including their children's education and health, as they get more educated and their reservation wage rises. As a consequence, women's labor supply may fall with increases in their education even though education also raises the opportunity cost of not working. Although we cannot test this labor supply channel directly, we show that the same observable factors that account for the decline in female LFPR over the two decades also account for the increase in female participation in domestic work, in the same proportions. This finding is not mechanical, since domestic work is only one component of the inactive - not in the labor force - category.

The remainder of the paper is organized as follows. In the next section we discuss the data we use in our analysis. In Section 3 we describe the decomposition methodology which 
quantifies the contribution of changing socio-economic characteristics to women's LFPR decline in India. We discuss results in Section 4 and conclude in Section 5.

\section{Data}

We use the Employment and Unemployment rounds of India's National Sample Surveys (NSS) in 1987-88, 1999-00 and 2009-10 (referred to as 1987, 1999 and 2009 in this paper). The surveys include repeated cross-sections of households, selected through stratified random sampling, that are representative of the country's population. ${ }^{5}$ The NSS provides data on individual and household characteristics - household composition, religion, social group, landholding, monthly consumption expenditure as well as age, education, marital status, and participation and earnings in the labor market. Throughout our analysis we measure an individual's labor force participation using the 'Usual Principal and Subsidiary Status (UPSS)' in the NSS which classifies a respondent as working or not working (inactive) during the reference period of 365 days preceding the date of survey (see Appendix A for details). ${ }^{6}$

Figure 1 shows the LFPR of 15-65 year old men and women in rural and urban India. It is immediately obvious that LFPRs are significantly higher for men and higher in rural areas. While labor force participation has been declining for 15-65 year old females and males in both rural and urban areas, the decline is dramatic for rural women: 12 percentage

\footnotetext{
${ }^{5}$ The NSS follows a two stage sampling design: In rural areas, the first stratum is a district. Villages are the primary sampling units (PSU), picked randomly in a district with equal number of households surveyed in each quarter (over an entire agricultural year of July to June) to ensure equal spacing of observations across the year. The households are randomly chosen in the selected PSUs.

${ }^{6}$ Throughout this paper we define the labor force participation rate as the proportion of people currently working or seeking work. Besides UPSS, the NSS provides another measure of labor force participation status 'Daily Status' - the number of days worked in the preceding week before the survey date. We do not use this measure in our analysis because the daily status employment rates in 1987 are not comparable to 1999 and 2009 due to a change in survey methodology. While these changes are unlikely to affect the employment rate using UPSS they can artificially increase the employment figures by daily status. However, none of our conclusions change if we use 'daily status' as our measure of employment.
} 
points between 1987 and $2009 .{ }^{7}$ When we restrict our sample to the 25-65 age group in Figure 2, there is no fall in the male LFPR over time. This is consistent with an increase in male school enrollment among the 15-24 year old group accounting for the reduction in the male LFPR over time (National Sample Survey Office 2015). However, in this older age group of 25-65, women's LFPR continues to exhibit a declining trend over time, and substantially so for rural India. This decline has been steeper between 1999 and 2009 (7 percentage points) than in the previous decade ( 3 percentage points). In Figure 3, we narrow down the demographic group experiencing declining work force participation to currently married women, who constitute 85 percent of the women in the $25-65$ age group. ${ }^{8}$ In Figure 4, we see that the decline in married women's LFPR has been accompanied by an almost equivalent increase in the proportion of these women who report domestic work as their primary activity in the previous 6 months during 1987-2009 (from 55 percent in 1987 to 65 percent in 2009). ${ }^{9}$

For the decomposition analysis we restrict our sample to 25-65 year old married women in rural India and use weights throughout to make our results nationally representative. Table 1 shows summary statistics of the variables used in the decomposition analysis for each of the three rounds of the NSS. The individual variables include age structure of women (seven indicator variables for age groups with age group 25-29 as the omitted category) and women's education (six indicator variables with illiterate as the omitted category). The household level variables are land owned by a household (five categories with the landholding size of less than 0.1 hectare as the omitted category),

\footnotetext{
${ }^{7}$ The decline in LFPR is 6 and 4 percentage points for rural and urban males, respectively, during this period. Urban women's LFPR declined by 5 percentage points between 1987 and 2009. The proportion of rural women looking for work has not changed during this period (NSS, various years). This suggests that it is not unemployment which is the cause of decline in women's LFPR.

${ }^{8}$ For never married females there has, in fact, been an increase in LFPR between 1987 and 2009. The share of married women in 1987, 1999 and 2009 was 82.5, 85.4, 86.4 percent, respectively (NSS survey rounds). The small but significant increase in this proportion is attributable to a lower proportion of widowed women due to falling mortality rates in India.

${ }^{9}$ Domestic work in the NSS includes domestic chores and not-for-wages collection of goods (vegetables, roots, firewood, cattle feed, etc.), sewing, tailoring, weaving, etc. for household use.
} 
household income deciles (ten indicator variables with the first decile omitted) and education of male members in a household (six indicator variables with illiterate as the omitted category). ${ }^{11}$ Since the NSS does not contain information on the income of households we use proxy for income using monthly household consumption expenditure. We create deciles of household monthly per capita consumption expenditure using the data for 1987 . The cut-off for each decile in 1987 is adjusted using the consumer price index for agricultural laborers and converted into its nominal value for 1999 and 2009. ${ }^{12}$ Because the NSS does not have relationship codes to match women to their husbands within households, we define male education as the highest education level among all 18-65 year old, married male members of the household. This variable proxies for differences in male earnings in the absence of selfemployment income in the NSS, and also captures assortative matching on education which has been rising during the period of our study. ${ }^{13}$

Table 1 indicates that while there have been no significant changes in the age structure of women, women's illiteracy rates have fallen dramatically from 80 to 56 percent between 1987 and 2009. The land ownership structure between 1987 and 1999 shows an increase in households with smaller landholdings. But there has been little change between 1999 and 2009. Real household incomes have increased with a larger percentage of women in the upper deciles of real household income in 2009 relative to 1987 . The educational

\footnotetext{
${ }^{11}$ The NSS provides data on the highest level of completed education and not years of schooling of household members. Therefore, to avoid measurement error in calculating the average years of schooling of men in the household we use the maximum level of male education. However, our results do not change if we use average education years. Other household characteristics which could possibly explain changes in women's employment, such as household size, share of children under age five, share of male members, caste and religion have not been included in the main regressions since they do not alter our main conclusions. Also, these characteristics can be endogenous to the labor force participation decision. The decomposition results including these variables are shown in robustness checks in Appendix B.

${ }^{12}$ To illustrate, the first decile contains households having a monthly per capita expenditure of less than Rs. 76 in 1987. In nominal terms Rs. 76 in 1987 is equivalent to Rs 213 and Rs 531 in 1999 and 2009 respectively. Rs. 213 is then defined to be the cut-off for the first decile in 1999. Similarly, Rs 531 is defined to be the cut-off for the first decile in 2009.

${ }^{13}$ The correlation between education of 18-35 year old daughters-in-law in the household with the highest education of married males who are sons of the household head has increased from 0.54 in 1987 to 0.64 in 2009 . We reach the same conclusion of a rise in assortative mating on education if we use the average level of education of males in the household.
} 
attainment of men in the household has also altered with a significant reduction in illiterate men ( 27 percent from 45 percent) and a larger proportion of married men completing at least middle school during this period.

\section{Methodology}

We use parametric and non-parametric decomposition methods to estimate the proportion of the decline in women's LFPR which can be attributed to the changing demographic and socio-economic characteristics of women. The data are classified into two periods - 19871999 and 1999-2009 - to account for the possibility that explanations for the decline in women's LFPR could differ between these two decades due to the liberalization of the economy initiated by the 1991 reforms in the country (e.g. Topalova 2010). Our decomposition techniques are described next. Our discussion refers to employment rates interchangeably with LFPRs, since there are no changes in the share of rural women seeking work (i.e. no changes in unemployment) over time.

\subsection{Parametric Decomposition: Blinder-Oaxaca}

We adopt the non-linear Blinder (1973) and Oaxaca (1973) technique to decompose the change in employment rates of women over time. We first estimate the following reduced form logit model for each year in our cross-sectional datasets:

$$
\widehat{Y}_{i}^{j}=F\left(\mathbf{X}_{i}^{j} \hat{\beta}^{j}\right)
$$

where $Y$ is the binary outcome variable - woman $i$ 's participation status in the labor force $(=1$ if the woman is currently in the labor force and 0 otherwise) in year $j ; \mathbf{X}$ comprises the individual and household characteristics as discussed in Table 1; and $\hat{\beta}^{j}$ are the parameter estimates. We can decompose the predicted differentials in participation rates between 1987 and 1999 using the coefficient estimates from (1) as follows: 


$$
\begin{aligned}
\bar{Y}^{1987}-\bar{Y}^{1999} & =\left[\sum_{i=1}^{N^{1987}} \frac{F\left(\mathbf{X}_{i}^{1987} \hat{\beta}^{1987}\right)}{N^{1987}}-\sum_{i=1}^{N^{1999}} \frac{F\left(\mathbf{X}_{i}^{1999} \hat{\beta}^{1987}\right)}{N^{1999}}\right] \\
& +\left[\sum_{i=1}^{N^{1999}} \frac{F\left(\mathbf{X}_{i}^{1999} \hat{\beta}^{1987}\right)}{N^{1999}}-\sum_{i=1}^{N^{1999}} \frac{F\left(\mathbf{X}_{i}^{1999} \hat{\beta}^{1999}\right)}{N^{1999}}\right]
\end{aligned}
$$

Here $\bar{Y}$ is the mean employment rate, and $N$ is the population size. The superscripts reflect the year of measurement.

The first term (in square brackets) on the right hand side of equation (2) represents the change in women's LFP that can be attributed to their changing demographic and socioeconomic characteristics $\left(\mathbf{X}_{\mathbf{i}}\right)$ over time holding the coefficients $\left(\hat{\beta}^{1987}\right)$ constant. We refer to this as the explained component of the variation in LFPR over time. The second term represents the change in women's LFPR holding $\mathbf{X}_{\mathbf{i}}$ constant while varying the coefficients over time. That is, it shows the change in women's LFPR explained by women with the same characteristics having different participation rates over time. We call this the unexplained component of the variation in LFPR over time. Dividing the explained (unexplained) component by the total change in female employment (i.e. the left hand side of (2)) gives us the explained (unexplained) proportion of the change in women's LFPR over time.

Equation (2) shows one version of the decomposition - when the coefficients for $1987\left(\hat{\beta}^{1987}\right)$ are assumed to represent the true relationship between female employment and individual characteristics. However, structural variations, such as a change in the supply and demand for women's labor could alter the relationship between women's employment and their characteristics over time. For instance, if $\hat{\beta}^{1999}<\hat{\beta}^{1987}$ for women in low income households, this could be because either female labor supply in these households or labor demand for these women fell (or a combination of the two). We will not be able to distinguish between these two explanations. However, to facilitate a comparison, in our 
analysis we estimate the explained proportion at the regression coefficients for two benchmark years $1987\left(\hat{\beta}^{1987}\right)$ and $1999\left(\hat{\beta}^{1999}\right)$ and discuss whether our findings differ depending on the specific year used to construct the decomposition.

\subsection{Semi-Parametric Decomposition}

We then employ a generalization of the Blinder-Oaxaca approach-a semi-parametric decomposition method first proposed by DiNardo, Fortin and Lemieux (1996) (henceforth, DFL), which does not impose a linear relationship between the dependent variable and the explanatory variables. ${ }^{14}$ We outline the DFL decomposition method below using the same notations as in Black, Tseng and Wilkins (2011).

Let $\mathrm{E}(e \mid x, t)$ denote the expected (mean) employment rate for people with a set of characteristics $x$ at time $t$ and let $f(x \mid t)$ denote the distribution of characteristics at time $t$. The aggregate employment rate at time $t$ can then be expressed as

$$
E(e \mid t)=\int E(e \mid x, t) f(x \mid t) d x
$$

The notation highlights the fact that both the employment-characteristic relationship $(E(e \mid x, t))$ and the distribution of characteristics $(f(x \mid t)$ can vary over time. To quantify the share of the fall in women's employment accounted for by the change in demographic and socio-economic characteristics of women (i.e. by changes in $f(x \mid t)$ ) we construct counterfactual employment rates as follows. We denote the time for which the set of employment rates for each characteristic is drawn by $t_{e}$, and the time from which the distribution of characteristics is drawn by $t_{x}$. The average employment rate at time $t$ can then be alternatively expressed as,

\footnotetext{
${ }^{14}$ DiNardo (2002) shows that the DFL method is identical to Blinder-Oaxaca decomposition when the variable of interest is the mean of the outcome variable and there is a single categorical explanatory variable. While this technique has been used to decompose wage and earnings differentials (Leibbrandt, Levinsohn, and McCrary 2010; Biewen 2001; Butcher and DiNardo 2002; Hyslop and Mare 2005; Daly and Valletta 2006), only a handful of papers have used it to decompose differences in other outcomes, such as, employment (Black, Tseng and Wilkins 2011) and health (Geruso 2012).
} 


$$
E\left(e \mid t_{e}=t, t_{x}=t\right)=\int E\left(e \mid x, t_{e}=t\right) f\left(x \mid t_{x}=t\right) d x
$$

where $E\left(e \mid t_{e}=1987, t_{x}=1987\right)$ denotes the observed employment rate in year 1987 given 1987 characteristics, while $E\left(e \mid t_{e}=1987, t_{x}=1999\right)$ denotes the counterfactual employment rate in 1987, i.e. the employment rate that would have been observed in 1987 had the distribution of individual characteristics been given by the distribution in 1999 . Holding the base year (1987) employment-characteristic relationship constant over time (this is analogous to the $\widehat{\beta}^{j}$ in our parametric approach), the change in aggregate employment between 1987 and 1999 can be decomposed into an explained component (change in employment due to change in socio-economic characteristics of working age women) and an unexplained component (change in employment due to change in employment rates of women with same characteristics) as follows:

Total change $=$ Explained change + Unexplained change

$$
\begin{aligned}
E\left(e \mid t_{e}\right. & \left.=1987, t_{x}=1987\right)-E\left(e \mid t_{e}=1999, t_{x}=1999\right) \\
& =\left[E\left(e \mid t_{e}=1987, t_{x}=1987\right)-E\left(e \mid t_{e}=1987, t_{x}=1999\right)\right] \\
& +\left[E\left(e \mid t_{e}=1987, t_{x}=1999\right)-E\left(e \mid t_{e}=1999, t_{x}=1999\right)\right]
\end{aligned}
$$

where the counterfactual employment rate in 1987 is given by:

$$
\begin{aligned}
E\left(e \mid t_{e}=1987, t_{x}=1999\right) & =\int E\left(e \mid x, t_{e}=1987\right) f\left(x \mid t_{x}=1999\right) d x \\
& =\int E\left(e \mid x, t_{e}=1987\right) \varphi(x) f\left(x \mid t_{x}=1987\right) d x
\end{aligned}
$$

$\varphi(x)$ is a re-weighting function which we use to adjust the distribution of characteristics in one year to look like the distribution of characteristics in a different year. We apply Baye's rule to get this re-weighting function:

$$
\varphi(x)=\frac{\operatorname{Pr}\left(t_{x}=1987\right)}{\operatorname{Pr}\left(t_{x}=1999\right)} \frac{\operatorname{Pr}\left(t_{x}=1999 \mid x\right)}{\operatorname{Pr}\left(t_{x}=1987 \mid x\right)}
$$


Where $\operatorname{Pr}\left(t_{x}=t\right)$ is the percentage of observations that belong to year $t$. The estimate for $\operatorname{Pr}\left(t_{x}=t \mid x\right)$ is obtained by estimating a discrete choice model where the dependent variable is a dichotomous variable for the observations belonging to year $t$ and $x$ are the explanatory characteristics. Then, $\varphi(x)$ is constructed using the predictions for each individual in year 1987.

The counterfactual employment rate that is part of (6) can then be empirically constructed as

$$
\hat{E}\left(e \mid t_{e}=1987, t_{x}=1999\right)=\sum_{i=1}^{N_{1} 987} \frac{\hat{\varphi}_{i}(x) e_{i}}{N_{1987}}
$$

where $\left(\hat{\varphi}_{i}(x)\right)$ is the estimated re-weighting function and $e_{i}$ is whether or not a woman is in labor force in year 1987. The estimated re-weights $\left(\hat{\varphi}_{i}(x)\right)$ are such that the distribution of observed characteristics across years is the same. ${ }^{15}$

We use both the Blinder-Oaxaca decomposition and the DFL decomposition to estimate the explained component of variation in LFPR over time using counterfactuals in 1987 and in 1999. We then repeat these exercises for the 1999-2009 decade and compare our results across methodologies and over time.

\section{Results}

Our main results appear in Tables 2 and 3. Note that because we estimate changes in female LFPR between 1987 and 1999 (i.e. 1987 minus 1999), and then between 1999 and 2009 (similarly, 1999 minus 2009), the changes are positive, because female LFPRs are declining over time.

\footnotetext{
${ }^{15}$ For example, in the above case, the observations in year 1987 are re-weighted such that the distribution of observed characteristics in 1987 is identical to that in 1999. If real income is higher in 1999, then a larger reweight is given to the individuals belonging to households having a higher income in 1987 so that the percentage of individuals in each income decile after re-weighting is identical across years.
} 


\subsection{Proportion of Decline in Women's LFPR Explained by Socio-economic}

\section{Characteristics}

Table 2 shows the parametric decomposition results. The specifications across columns differ in the individual and household characteristics included in the analysis. We include age of the woman and her education as the only explanatory characteristics in the first specification (column (1)). Household land ownership (column (2)) and household income are added in column (3). In column (4), we replace household income with the highest level of education among men in the household, which is more likely to be exogenous to women's LFPR than household income. Column (5) includes all of these demographic and socio-economic characteristics.

Panel A of Table 2 shows the decomposition results for the change in women's LFPR between 1987 and 1999. We calculate the explained proportion of total predicted change in female LFPR by dividing the explained component by the change in predicted LFPR. For instance, in Panel A column (1), the explained proportion at 1987 coefficients is $0.0210 / 0.0310=0.68$. This means that 68 percent of the change in female LFPR between 1987 and 1999 can be accounted for by the changing structure of female education and the distribution of women across age groups, keeping the 1987 coefficients constant. Across specifications in Table 2, Panel A, the share of the change in female LFPR that can be explained by observables varies from 68 to 136 ( 70 to 141) percent when we use the 1987 (1999) coefficients. When all variables are included, the share of the change that we can account for is 136 (140) percent evaluated at the regression coefficients for the year 1987 (1999). This implies that the included demographic and socio-economic attributes fully explain the fall in women's LFPR between 1987 and 1999. Explained proportions greater than one suggest that if only these attributes were responsible for the change in women's LFPR during this period, then the fall in female LFPR should have been larger than we 
observe. In other words, the effects of the included variables on the change in female LFPR must have changed size possibly also sign over time.

Panel B shows the decomposition results for 1999-2009. When all the demographic and socio-economic characteristics of women are included in our analysis (column (5)), only 50 (19) percent of the decline in women's LFPR in this period can be explained at the 1999 (2009) employment regression coefficients as indicated in column (5). Thus, we can account for a higher proportion of the fall in women's LFPR during 1999-2009 using the 1999 coefficients than using the 2009 coefficients. As discussed earlier, the employment regression coefficients for 1999 are likely to reflect the relationship between employment and individual characteristics given specific labor demand conditions in 1999. Changing labor demand over time, especially in response to the economic reforms of the 1990s, could have altered the observed relationship between characteristics and employment in 2009. We discuss this issue in more detail later.

We now consider the estimates obtained from the non-parametric DFL decomposition technique in Table 3. For brevity, we show only the calculated explained proportions (that is, the share of the predicted variation in female LFPR accounted for by the specific set of observable characteristics). Panel A indicates that between 67 and 141 percent (69 and 146 percent) of the fall in women's LFPR between 1987 and 1999 can be explained, depending on the demographic and socio-economic characteristics we include, at the counterfactuals for 1987 (1999). Similarly, 34-53 percent (13-19 percent) of the fall in women's LFPR between 1999 and 2009 is accounted for by the included characteristics at the counterfactuals for 1999 (2009) in Panel B. These explained proportions are very similar to those obtained in Table 2 using Blinder-Oaxaca decomposition. The largest difference in the explained component obtained by the two methods is when we use the 2009 coefficients. In this case, the Blinder Oaxaca decomposition tells us we can account for 19 percent of the predicted change 
between 1999 and 2009, while the DFL estimate only accounts for 14 percent of the predicted change (comparing column (5) in Tables 2 and 3).

To check the validity of the semi-parametric results, Black, Tseng and Wilkins (2011) suggest conducting $t$ tests for individual variable means, across the re-weighted observations in the base year and the actual observations in the other year(s). The null of equality of means is more likely to be accepted when the re-weighting function is precisely estimated for which, they advocate inclusion of interaction terms among the characteristics. As a robustness check, therefore, we show the DFL decomposition results when all two-way interaction terms between observables are included as explanatory variables while estimating the re-weighting function in column (6) of Table 3. ${ }^{16}$ These estimates are comparable to those shown in column (5), in which we do not include interaction terms among the set of characteristics. ${ }^{17}$

\subsection{Contribution of characteristics to the predicted changes in female LFPR}

The above results show that the explained proportions estimated using both the parametric and the non-parametric techniques are quite similar. This gives us confidence in the BlinderOaxaca decomposition results. However, they only give us an overall picture of how the set of included observables, along with the year-specific coefficients on these variables, account for the changes in female LFPR over time. In order to better understand the relative role of different characteristics, we use a method proposed by Fairlie (2005). For each specific observable characteristic, we estimate how much of the total predicted change in female LFPR is accounted for by that characteristic and its year-specific coefficient, conditional on

\footnotetext{
${ }^{16}$ For instance, we interact age-group with education, land owned, income, male education and own education separately.

${ }^{17}$ In specification (6) the re-weighting function is unable to match the age-group composition at statistically significant levels, but the absolute differences are not large. For example, in Panel A, specification 6, the reweighted observations in 1987 have an age group composition of 22, 20, 17, 13,11,8 and 10 percent for age groups 25-29, 30-34, 35-39, 40-44, 45-49, 50-54 and 55-65 respectively. The corresponding numbers for actual population in 1999 provided in Table 1 are very close to these proportions.
} 
the other variables included in the regression. We do this using the Blinder-Oaxaca regressions, in Table 4.

Panel A shows the contribution of each characteristic to the total explained component (in bold) in 1987-1999 at the regression coefficients for 1987. This is obtained by dividing the characteristics' contribution (in the row below the bold figures) by the total explained component for that specification in Table 2. For instance, in specification (1), woman's education contributes fully to the explained proportion, because $0.0213 / 0.0210 \approx$ 1.02. ${ }^{18}$ In specifications (2) and (3) we include land and household income, and we see the contribution of education to the explained proportion of change in female LFPR falls to 81 and then 58 percent in specifications (2) and (3). This is due to the correlations between all of these included variables. However, as we look across columns (1) - (3), woman's own education continues to be the largest contributor to the explained proportion of changing female LFPR. Adding controls for the education of men in the household, in columns (4) and (5) reduces the contribution of women's education to the explained component by more than half. This likely indicates strong assortative matching: educated women matched to educated men in the marriage market in India (Dalmia 2011). The rise in men's education constitutes 54 to 62 percent of the explained component of the fall in women's LFPR between 1987 and 1999. Across all columns for Panel A, women's own education and the education of the men in their household together can account for 70 to 84 percent of the explained component of the decline in women's LFPR between 1987 and 1999.

Decrease in per capita landholding of the household contributes 17 to 22 percent to the explained component during this period across specifications in Panel A. This is likely because women belonging to households with more land have a larger probability of being employed (primarily due to self-employment on own land). Increases in household income

\footnotetext{
${ }^{18}$ Rounding off errors in Table 4.
} 
constitute 12 to 21 percent of the explained component of the fall in women's LFPR during 1987-1999, depending on the specification we use. The results follow a similar pattern when the explained proportion is evaluated at the 1999 coefficients - with own and male education contributing between 62 and 75 percent to the explained component.

During the 1999-2009 decade (Panel B of Table 4) increases in women's and men's education were again the largest contributors to the explained proportion. When all the characteristics are included (column 5), women's education constitutes 32 (59) percent of the explained component at 1999 (2009) coefficients. Similarly, male education contributes 42 (73) percent to the explained proportion. Change in households' landholdings contributes negligibly to the explained component during this decade as shown in Panel B. Of note is the role of household income in predicting the fall in female LFPR. While household income accounts for 27-36 percent of the explained component when evaluated at the regression coefficients for 1999, the negative proportion obtained for the 2009 coefficients suggests that increases in income should have resulted in an increase in women's LFPR during this period. That is, because the overall change in female LFPR is negative, rising household incomes should have mediated this decline. The effect of increasing household incomes is not consistent over time. Overall, the magnitude of the contribution of the non-education variables to explaining female LFPR between 1999 and 2009 is significantly smaller than the contribution of the education variables. ${ }^{19}$

Based on the figures in Table 4, we can estimate the contribution of education to the actual decline in women's LFPR. In specification (5) of Table 4, Panel A, the contribution of

\footnotetext{
${ }^{19}$ The proportion of explained variation falls when additional variables are included in Appendix B. The female characteristics continue to explain the entire fall in female LFPR between 1987 and 1999. the explained proportion between 1999 and 2009 falls to 40 percent. This is because household size and number of children under age five have reduced over time and this should have resulted in an increase in female LFPR. Social group membership and male members do not contribute much to the explained proportion. The only additional characteristic which explains the decline in female LFPR between 1999 and 2009 is change in religious composition as the proportion of population that is Muslim has increased and Muslim women tend to have lower participation rates in the labor market. Our main conclusion that individual and household characteristics, in particular education, play the most important role in explaining the decline does not change.
} 
women's education to the explained variation in LFPR over the first decade is 16 percentage points while the explained proportion is 136 percent (Table 2) at the regression coefficients for 1987. This implies that changes in women's education over time explain about 21.8 percent $(=0.16 \times 1.36)$ of the total decline in female LFPR. Using this method, we estimate that women's own education and that of the men in their household (specification 5) accounts for between 87-95 percent of the overall decline in women's LFPR in 1987-1999 depending on whether we use 1987 or 1999 coefficients. In the 1999-2009 decade, they explain 25-37 percent of the total decline in women's LFPR. In both decades, education is the largest contributor to the decline in women's LFPR. This is in contrast to what we might have expected, that increasing female education leads to increases in women's work.

\subsection{Discussion of Results}

\subsubsection{Mechanism for the role of education in the decline of the female LFPR}

One potential mechanism that can explain the negative impact of rising women's education on their labor market participation is a possible rise in the returns to women's home productivity. This could either be a result of an increase in productivity of time spent by women in home production or a change in preferences of women towards home production as their education increases. In either case, if the returns to women's time spent in home production rise faster than the returns to female education in the labor market, then women are likely to withdraw from the labor market as they become more educated. To investigate this potential explanation further we use the same decomposition techniques to analyze one measure of home production - domestic work by women in the household - in the NSS.

As shown in Figure 4, the decline in married women's employment in rural India over the last 30 years has been accompanied by an increase in the proportion of women reporting domestic work as their primary activity. Table 5 shows the non-linear Blinder-Oaxaca 
decomposition results for the change in domestic work by women between 1987-1999 and 1999-2009. The included attributes of women fully account for the rise in domestic work between 1987 and 1999 (columns (1) and (2)) and account for up to 64 percent of the increase between 1999 and 2009 (columns (3) and (4)) as shown by the row 'explained proportion'. ${ }^{20}$

The rise in women's education over the first decade in our sample accounts for 45 (36) percent of the explained proportion at the 1987 (1999) regression coefficients (specification 1 of Table 5). Similarly, women's education contributes 38 (67) percent to the explained proportion of the surge in domestic work using the 1999 (2009) regressions coefficients (specification 3 of Table 5) for the later decade, 1999-2009. Controlling for men's education in specifications (2) and (4) reduces these explained proportions by about a third. ${ }^{21}$ The growth in household income also explains a substantial part of the rising proportion of women engaging primarily in domestic work in both decades. However, decreases in per capita landholdings contribute to the increased participation in domestic work only during the earlier period, 1987-1999.

These results show that the same key variables that accounted for a substantial part of the predicted decline in female LFPR over time in both decades - that is, the education variables - also account for a substantial share of the predicted increase in female domestic work over the same period. These findings are therefore consistent with increasing relative returns to education in home production being a possible mechanism for the decline in female LFPR in rural India. Whether this is due to an increase in their home productivity or a shift in preferences is not something we can test in our data. However, findings from other research

\footnotetext{
${ }^{20}$ The DFL results for the decomposition of domestic work are similar to those obtained by Oaxaca-Blinder method and hence have been omitted for brevity.

${ }^{21}$ Increase in women's and men's education explains 17 percent ( 75 percent) and 20 percent ( 60 percent) of the increase in domestic work using 1987 (1999) regressions coefficients respectively (specification 2 of Table 5) during 1987-1999. Similarly, female (male) education explains 9 percent (27 percent) and 4 percent (15 percent) of the increase in domestic work using 1999 (2009) regressions coefficients (specification 4 of Table 5) during 1999-2009.
} 
support the interpretation that education makes women more productive in the home. First, returns to education in home production may have increased during the period of our study if the returns to children's human capital rose during this period as well. Behrman et al. (1999), using data from the green revolution period in India (1968-1982) find that the returns to male education increased since households with an educated male member earned larger farm profits. This in turn increased the demand for educated women in the marriage market.

Women with primary education spent more time at home and presence of an educated mother increased time spent by children studying, relative to less educated mothers. More recently, Azam (2012) finds that in urban India, increases in the returns to education during 1993-2004 were much higher for workers with secondary and tertiary education. Similarly, Mendiratta and Gupt (2013) find that there has been an increase in returns to education in India during 2004-2009 but only at more than secondary levels of education. The empirical evidence on changes in returns to schooling in India is consistent with households investing in more education for their children. Second, in a recent paper, Kharbanda (2012), using data from 2004-05, finds that returns to education in the market increase at a higher rate after the first seven years of schooling in India. It seems that in rural India, it is possible that the recent changes in female education (especially in primary education) have added more to women's marginal productivity in the home than in the market, at least for those women with children in middle school. Indeed, we find that the decline in the LFPR of women aged 25-40, compared to 40-65 year olds, was greater in both decades. ${ }^{22}$ It is these younger women who are more likely to have children of school-going age -almost twice as many 6-14 year old children as women aged 40-65 - in the NSS.

\footnotetext{
22 The LFPR of 25-40 year old, married rural women declined 3.7 and 10.2 percentage points during 1987-1999 and 1999-2009, respectively. The corresponding numbers for 40-65 year old women was 1.9 and 6.7.
} 


\subsubsection{Other factors accounting for the unexplained changes in female LFPR}

While the changes in demographic and socio-economic attributes of women completely explain the fall in their LFPR during 1987-1999, 50 percent or more of the fall in women's LFPR in 1999-2009 remains unexplained. What factors might account for this unexplained component in the later period?

The unexplained proportion could reflect changes in the demand for women's labor interacting with increases in female education. A lower demand for female labor will reduce the probability of women's participation in the labor market even when their individual and socio-economic characteristics are unchanged. Structural transformation in the economy, in which labor reallocates out of agriculture and into other sectors, as has occurred in India during the last couple of decades, could impact female employment through this labor demand channel (Goldin 1995). Typically, wages in the agriculture sector are the lowest in India and hence females are likely to withdraw from this sector as education and real income growth raise their reservation wages. ${ }^{23}$ Other sectors - construction, manufacturing and services - should then grow at a pace that can absorb labor that has withdrawn from agriculture. While economic growth in India in the last few decades has resulted in a decline in the contribution of agriculture to employment growth, it has failed to create concomitant growth in the manufacturing sector where most women with middle to secondary levels of education and from middle income groups are likely to look for employment (Chandrasekhar and Ghosh 2011). During 1999 and 2009, female employment in agriculture fell by 9 percentage points, and fell in manufacturing from 3.7 percent to 3.3 percent. Female employment in the construction sector rose by only 3 percentage points while there was no change in the services sector (authors' calculations from the NSS 1999 and 2009). Thus, economic growth has not been able to absorb female workers leaving agricultural work

\footnotetext{
${ }^{23}$ Authors' calculations show that in 2009 daily wage in agriculture, manufacturing, construction and services sectors were Rs. 67, Rs. 83, Rs. 93 and Rs. 159, respectively.
} 
(Chowdhury 2011; Kannan and Raveendran 2012). A rise in women's own education coupled with lack of jobs commensurate with higher reservation wages may contribute to the continued decline in female LFPR, especially in the second decade of our sample.

\section{Conclusion}

In India, women's labor force participation rates fallen quite dramatically over the last three decades, which has also been a period of rapid growth in incomes and educational attainment. We show that this decline has been concentrated among rural, married women. This group has also increased participation in domestic work over the same period.

We use parametric and non-parametric decomposition techniques to estimate the proportion of the fall in women's LFPR that can be accounted by the changing characteristics of working age women. Our analysis shows that the magnitude of the proportion of the fall in women's LFPR which can be explained by observable attributes is large, albeit falling over time. While the fall in women's LFPR between 1987 and 1999 is completely explained by the changes in women's demographic and socio-economic characteristics, they account for at most 50 percent of the fall between 1999 and 2009.

Among the individual attributes, the decomposition exercise shows that increases in women's own education and that of the men in their household plays the most important role in explaining the decline in female LFPR in both decades. At a minimum, increases in women's and men's education explain 22 percent and 54 percent of the total fall between 1987 and 1999 respectively. Similarly, increases in education of women and men account for at least 11 percent and 14 percent of the decline in rural women's LFPR between 1999 and 2009 , respectively. We highlight the role of education in the observed fall in women's LFPR in India in the previous three decades coupled with an increasing proportion of these women engaging primarily in domestic, non-remunerative activities. 
We suggest a hitherto ignored explanation for the fall in women's LFPR - the role of women in home production. If the returns to women's home production rise more than the returns in the labor market for educated females, women are likely to withdraw from the labor force and engage in domestic work. We provide evidence that suggests that this may be a credible and important factor in explaining the long-term trend of declining women's LFPR in India.

Compliance with Ethical Standards:

Funding: This study was funded by IGC - India, Project Code: 1-VRA-VINC-VXXXX89217

Conflict of Interest: The authors declare that they have no conflict of interest. 


\section{References}

Aromolaran, Adebayo B. 2004. "Female schooling, non-market productivity and labor market participation in Nigeria." Center Discussion Paper No 879, Yale University, USA.

Azam, Mehtabul. 2012. "Changes in wage structure in urban India, 1983-2004: A quantile regression decomposition.” World Development 40, no. 6:1135-1150.

Behrman, Jere R., Andrew D. Foster, Mark R. Rosenweig, and Prem Vashishtha. 1999. "Women's schooling, home teaching, and economic growth." Journal of Political Economy 107 (4): 682-714.

Biewen, Martin. 2001. "Measuring the effects of socio-economic variables on the income distribution: an application to the East German transition process." Review of Economics and Statistics 83, no. 1:185-90.

Black, David, Tseng, Yi-Ping, and Roger Wilkins. 2011. "Do changes in demographic characteristics explain declining male employment rates? Examination of the Australian case using a propensity score re-weighting decomposition approach." Applied Economics 43 (28):4215-4226.

Blinder, Alan S. 1973. "Wage discrimination: reduced form and structural estimates." Journal of Human Resources, 8:436-455.

Butcher, Kristin F., and John DiNardo. 2002. "The immigrant and native-born wage distributions: evidence from United States censuses." Industrial and Labor Relations Review $56(1): 97-121$.

Cameron, Lisa A., Dowling, J. Malcolm, and Christopher Worswick. 2001. "Education and labor market participation of women in Asia: Evidence from five countries." Economic Development and Cultural Change 49 (3):459-477.

Chandrasekhar, C.P. and Jayati Ghosh. 2011. "Latest employment trends from the NSSO", The Hindu Business Line, 12 July.

Chatterjee, Urmila, Murgai, Rinku, and Martin Rama. 2014. "Job opportunities along the rural-urban gradation and female labor force participation in India." Mimeo.

Chowdhury, Subhanil. 2011. "Employment in India: What does the latest data show?" Economic and Political Weekly 34 (32):23-26.

Dalmia, Sonia. 2011. "Testing Becker's efficient marriage market hypothesis and its implications for spouse selection and marital transfers in India." Journal of Business \& Economics Research 2 (4):1-8.

Daly, Mary C., and Robert G. Valletta. 2006. "Inequality and poverty in United States: the effects of rising dispersion of men's earnings and changing family behavior." Economica 73 (289):75-98. 
Das, Maitreyi Bordia, and Sonalde Desai. 2003. "Are educated women less likely to be employed in India?" Social Protection Discussion Paper No. 313, World Bank, Washington DC.

Das, Sonali, Jain-Chandra, Sonali, Kochchar, Kalpana, and Naresh Kumar. 2015. "Women workers in India: Why so few among so many?” IMF Working Paper WP/15/55.

DiNardo, John. 2002. "Propensity score reweighting and changes in wage distributions." Mimeo, University of Michigan, Ann Arbor.

DiNardo, John, Fortin, Nicole M., and Thomas Lemieux. 1996. "Labor market institutions and the distribution of wages, 1973-1992: A semiparametric approach." Econometrica 64 (5):1001-1044.

Eswaran, Mukesh, Ramaswami, Bharat, and Wilima Wadhwa. 2013. "Status, caste, and the time allocation of women in rural India." Economic Development and Cultural Change 61 (2):311-333.

Fairlie, Robert W. 2005. "An extension of the Blinder-Oaxaca decomposition technique to logit and probit models." Journal of Economic and Social Measurement 30 (4):305-316.

Gaddis, Isis, and Stephan Klasen. 2014. "Economic development, structural change and women's labor force participation.” Journal of Population Economics 27 (3):639-681.

Geruso, Michael. 2012. "Black-white disparities in life expectancy: how much can the standard ses variables explain?” Demography 49 (2): 553-574.

Goldin, Claudia. 1995. "The U-shaped female labor force function in economic development and economic history." In Investment in Women's Human Capital, ed. T. Paul Schultz. Chicago: University of Chicago Press, pp. 61-90.

Himanshu. 2011. "Employment trends in India: A re-examination." Economic and Political Weekly 46 (37):43-59.

Hyslop, Dean R., and David C. Mare. 2005. "Understanding New Zealand's changing income distribution, 1983-1998: A semi-parametric analysis.” Economica 72, no. 287:469-495.

Kannan, K.P., and G. Raveendran. 2012. "Counting and profiling the missing labor force." Economic and Political Weekly 47 (6):77-80.

Kapsos, Steven, Silberman, Andrea, and Bourmpoula, Evangelia. 2014. "Why is female labour force participation declining so sharply in India?” ILO Research Paper No. 10.

Kharbanda, Varun. 2012. "Returns to education in India." Mimeo, University of Iowa.

Klasen, Stephan, and Janneke Pieters. 2015. "What explains the stagnation of female labor force participation in urban India?" Policy research working paper 7222. World Bank Group, Washington, D.C. 
Lahoti, Rahul, and Hema Swaminathan. 2013. "Economic growth and female labor force participation in India." Working paper no. 414, Indian Institute of Management, Bangalore.

Lam, David, and Suzanne Duryea. 1999. "Effects of schooling on fertility, labor supply, and investments in children, with evidence from Brazil." Journal of Human Resources 34(1):160192.

Leibbrandt, Murray, Levinsohn, James A., and Justin McCrary. 2010. "Incomes in South Africa after the fall of apartheid. " Journal of Globalization and Development 1(1).

Lincove, Jane Arnold. 2008. "Growth, girls' education, and female labor: A longitudinal analysis.” Journal of Developing Areas 41 (2):45-68.

Mendiratta, Priti, and Yamini Gupt. 2013. "Private returns to education in India by gender and location: A Pseudo-Panel Approach."

http://www.econcaluniv.ac.in/arthanitiweb/book/2013/PM.pdf (accessed on November 11, 2015).

National Sample Survey Office. 2011. "Key Indicators of Social Consumption in India Education." http://mospi.nic.in/Mospi_New/upload/nss_71st_ki_education_30june15.pdf (accessed November 10, 2015).

Neff, Daniel, Sen, Kunal, and Veronika Kling. 2012. "The puzzling decline in rural women's labor force participation in India: A re-Examination." GIGA working paper no. 196, GIGA Research Unit, Institute of Asian Studies.

Oaxaca, Ronald. 1973. "Male-female wage differentials in urban labor markets." International Economic Review 14 (3):693-709.

Sorsa, P. et al. 2015. "Determinants of the low female labour force participation in India", OECD Economics Department Working Papers, No. 1207, OECD Publishing, Paris.

Tam, Henry. 2011. "U-shaped female labor participation with economic development: Some panel data evidence." Economics Letters 110 (2):140-142.

Topalova, Petia. 2010. "Factor immobility and regional impacts of trade liberalization: evidence on poverty from India," American Economic Journal: Applied Economics, 2(4):141.

United Nations. 2013. Millennium Development Goals Report.

http://www.un.org/millenniumgoals/pdf/report-2013/mdg-report-2013-english.pdf (accessed October 12, 2015)

World Bank. 2012. World Development Report 2012: Gender Equality and Development. http://siteresources.worldbank.org/INTWDR2012/Resources/77781051299699968583/7786210-1315936222006/Complete-Report.pdf (accessed November 18, 2013). 
Figure 1. Labor Force Participation Rates (LFPR) by Gender (15-65 years)

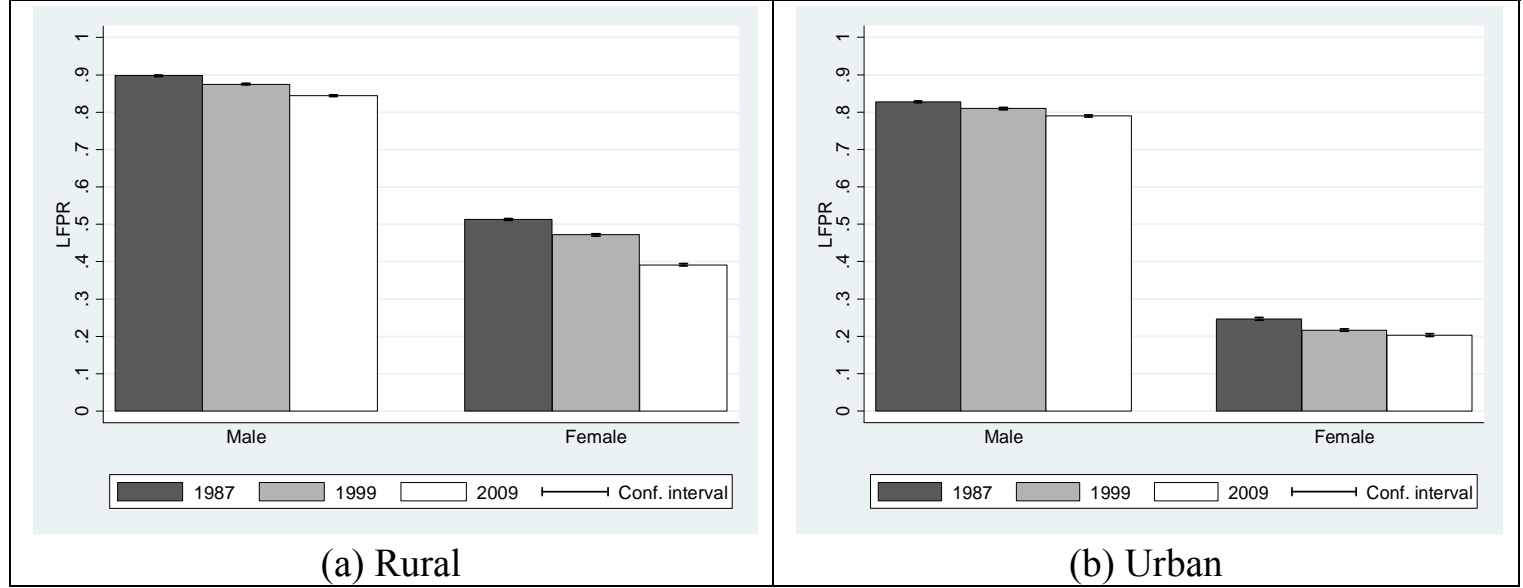

Source: NSS $(1987,1999,2009)$ Employment and Unemployment Schedule (Authors' calculations).

Figure 2. Labor Force Participation Rates (LFPR) by Gender (25-65 years)

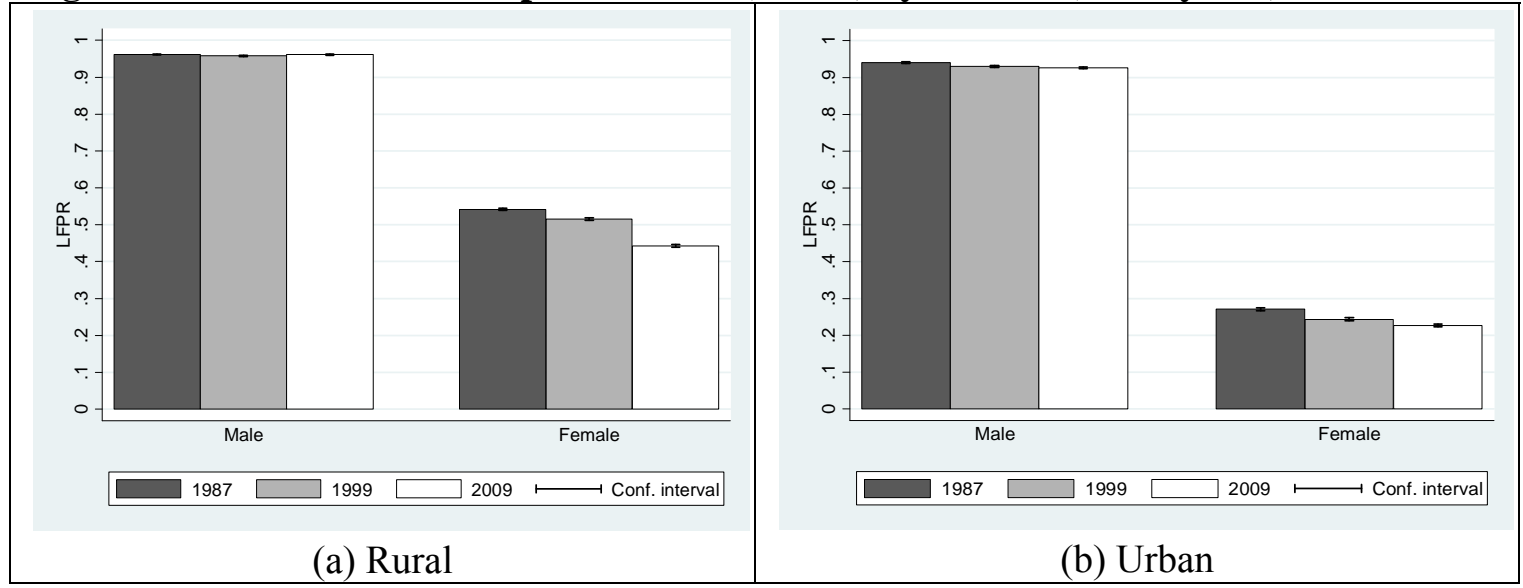

Source: NSS (1987, 1999, 2009) Employment and Unemployment Schedule (Authors' calculations). 
Figure 3. Female Labor Force Participation (LFPR) Rates by Marital Status (Rural)

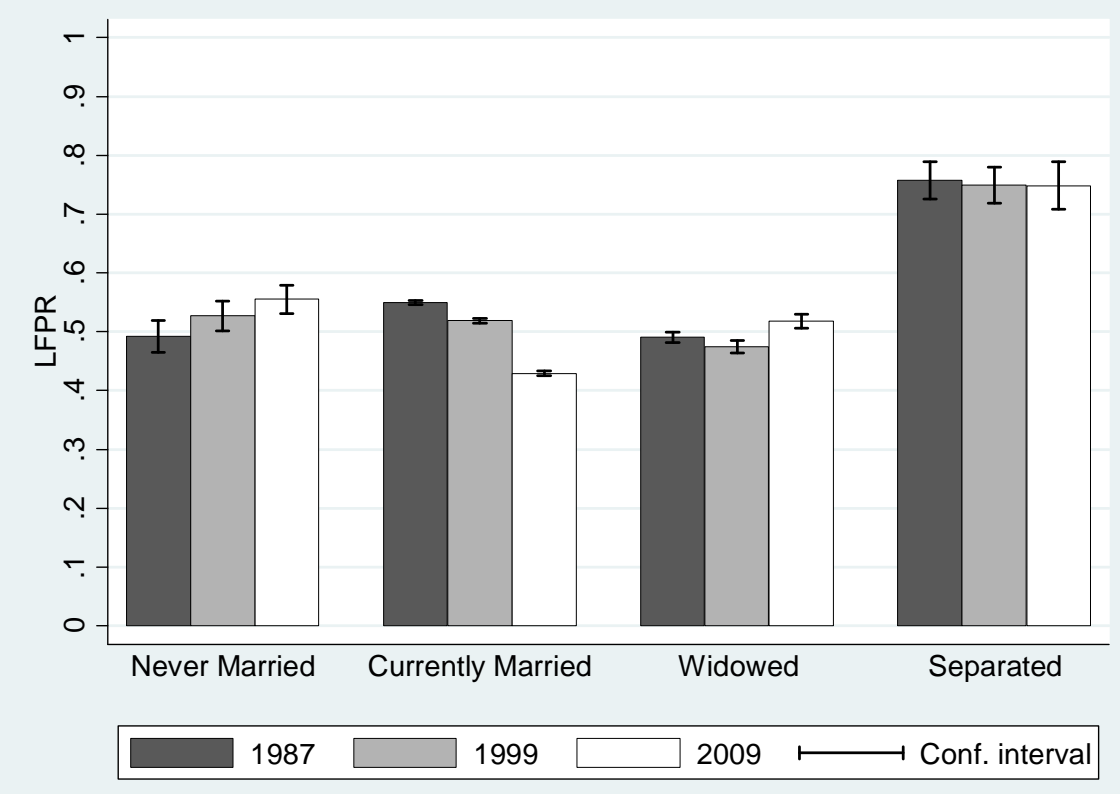

Source: NSS (1987, 1999, 2009) Employment and Unemployment Schedule (Authors' calculations).

Note: The sample includes women aged 25-65 in rural India. The mean share of women married across years is 0.85 .

Figure 4. Female Participation in Domestic Work by Marital Status (Rural)

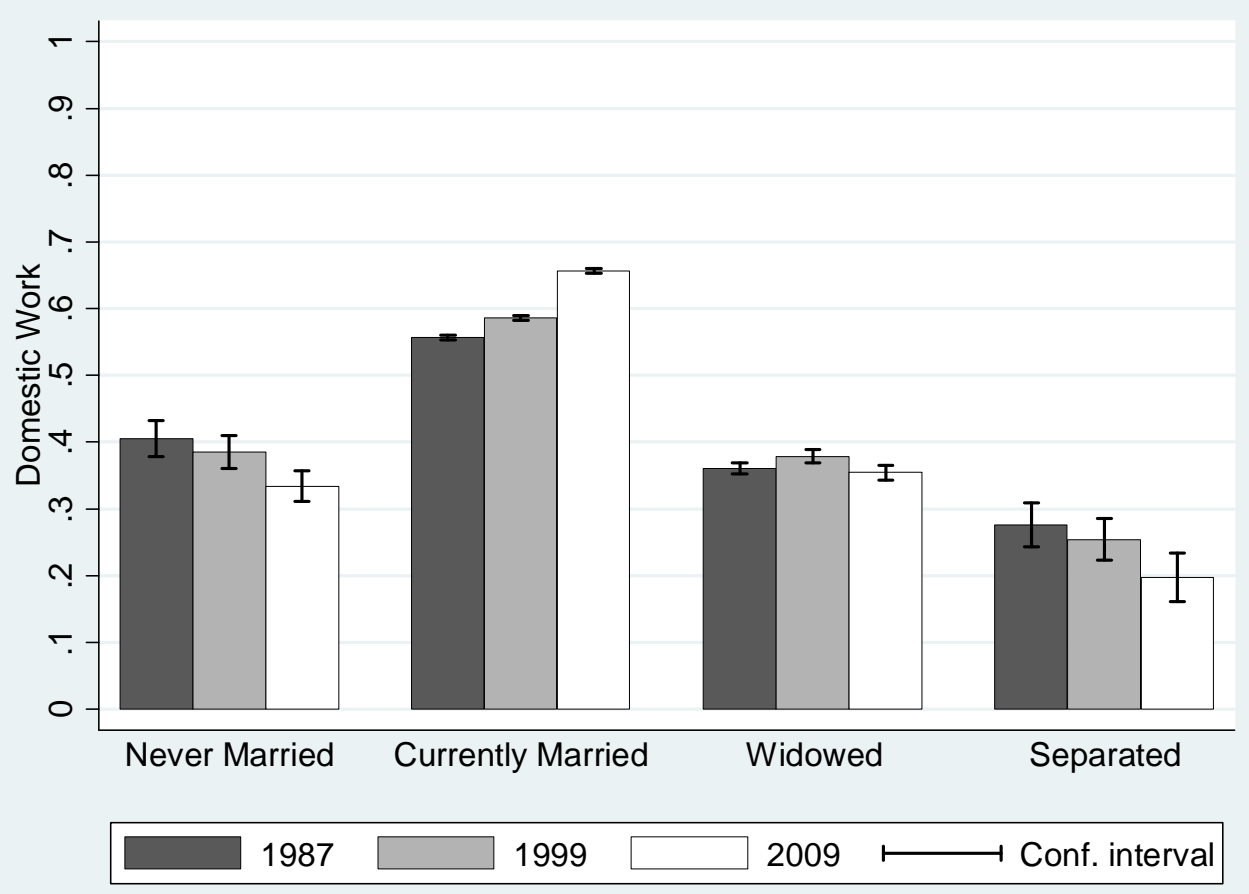

Source: NSS (1987, 1999, 2009) Employment and Unemployment Schedule (Authors' calculations). The mean share of women married across years is 0.85 .

Note: The sample includes women aged 25-65 in rural India. The above graph reports proportion of women whose primary activity is domestic work. 
Table 1: Summary Statistics

\begin{tabular}{|c|c|c|c|c|c|c|c|}
\hline \multirow{3}{*}{$\begin{array}{l}\text { Variable } \\
\\
\text { Age (years) }\end{array}$} & \multirow{3}{*}{$\begin{array}{l}\text { Description } \\
25-29\end{array}$} & \multicolumn{6}{|c|}{ Mean (Standard Error) } \\
\hline & & \multicolumn{2}{|c|}{$\begin{array}{c}1987 \\
(\mathrm{~N}=73,833)\end{array}$} & \multicolumn{2}{|c|}{$\begin{array}{c}1999 \\
(\mathrm{~N}=67,108)\end{array}$} & \multicolumn{2}{|c|}{$\begin{array}{c}2009 \\
(\mathrm{~N}=57,511)\end{array}$} \\
\hline & & 0.23 & $(0.0015)$ & 0.21 & $(0.0016)$ & 0.19 & $(0.0016)$ \\
\hline & $30-34$ & 0.19 & $(0.0014)$ & 0.19 & $(0.0015)$ & 0.18 & $(0.0016)$ \\
\hline & $35-39$ & 0.16 & $(0.0014)$ & 0.17 & $(0.0014)$ & 0.18 & $(0.0016)$ \\
\hline & $40-44$ & 0.13 & $(0.0012)$ & 0.13 & $(0.0013)$ & 0.14 & $(0.0014)$ \\
\hline & $45-49$ & 0.11 & $(0.0012)$ & 0.10 & $(0.0012)$ & 0.11 & $(0.0013)$ \\
\hline & $50-54$ & 0.08 & $(0.001)$ & 0.08 & $(0.001)$ & 0.08 & $(0.0011)$ \\
\hline & $55-65$ & 0.10 & $(0.0011)$ & 0.12 & $(0.0012)$ & 0.13 & $(0.0014)$ \\
\hline \multirow{6}{*}{ Education } & Illiterate & 0.80 & $(0.0015)$ & 0.71 & $(0.0018)$ & 0.56 & $(0.0021)$ \\
\hline & Less than primary & 0.07 & $(0.001)$ & 0.09 & $(0.0011)$ & 0.11 & $(0.0013)$ \\
\hline & Primary & 0.07 & $(0.0009)$ & 0.08 & $(0.0011)$ & 0.12 & $(0.0014)$ \\
\hline & Middle & 0.03 & $(0.0007)$ & 0.07 & $(0.001)$ & 0.11 & $(0.0013)$ \\
\hline & Secondary - High Secondary & 0.02 & $(0.0005)$ & 0.04 & $(0.0008)$ & 0.08 & $(0.0012)$ \\
\hline & Graduate and above & 0.00 & $(0.0002)$ & 0.01 & $(0.0003)$ & 0.02 & $(0.0006)$ \\
\hline \multirow{5}{*}{$\begin{array}{l}\text { Household's } \\
\text { landownership }\end{array}$} & less than 0.1 hectare & 0.51 & $(0.0018)$ & 0.60 & $(0.0019)$ & 0.61 & $(0.002)$ \\
\hline & $0.1-0.2$ hectare & 0.16 & $(0.0014)$ & 0.15 & $(0.0014)$ & 0.14 & $(0.0014)$ \\
\hline & $0.2-0.4$ hectare & 0.16 & $(0.0013)$ & 0.13 & $(0.0013)$ & 0.13 & $(0.0014)$ \\
\hline & $0.4-0.6$ hectare & 0.07 & $(0.0009)$ & 0.05 & $(0.0009)$ & 0.06 & $(0.001)$ \\
\hline & More than 0.6 hectare & 0.10 & $(0.0011)$ & 0.06 & $(0.0009)$ & 0.06 & $(0.001)$ \\
\hline \multirow{10}{*}{$\begin{array}{l}\text { Household's } \\
\text { income decile }\end{array}$} & First (< Rs. 76) & 0.09 & $(0.0011)$ & 0.06 & $(0.0009)$ & 0.03 & $(0.0007)$ \\
\hline & Second (Rs. 76 - 93) & 0.11 & $(0.0012)$ & 0.08 & $(0.001)$ & 0.05 & $(0.0009)$ \\
\hline & Third (Rs. 93 - 107) & 0.11 & $(0.0012)$ & 0.09 & $(0.0011)$ & 0.06 & $(0.001)$ \\
\hline & Fourth (Rs. $107-121$ ) & 0.10 & $(0.0011)$ & 0.11 & $(0.0012)$ & 0.08 & $(0.0011)$ \\
\hline & Fifth (Rs. 121 - 135) & 0.10 & $(0.0011)$ & 0.11 & $(0.0012)$ & 0.09 & $(0.0012)$ \\
\hline & Sixth (Rs. 135 - 153) & 0.10 & $(0.0011)$ & 0.12 & $(0.0012)$ & 0.11 & $(0.0013)$ \\
\hline & Seventh (Rs. 153 - 177) & 0.10 & $(0.0011)$ & 0.13 & $(0.0013)$ & 0.13 & $(0.0014)$ \\
\hline & Eighth (Rs. 177 - 212) & 0.10 & $(0.0011)$ & 0.12 & $(0.0012)$ & 0.15 & $(0.0015)$ \\
\hline & Ninth (Rs. 212 - 281) & 0.10 & $(0.0011)$ & 0.11 & $(0.0012)$ & 0.16 & $(0.0015)$ \\
\hline & Tenth (> Rs. 281) & 0.09 & $(0.0011)$ & 0.08 & $(0.001)$ & 0.14 & $(0.0014)$ \\
\hline \multirow{6}{*}{$\begin{array}{l}\text { Household's } \\
\text { highest male } \\
\text { education }\end{array}$} & Illiterate & 0.45 & $(0.0019)$ & 0.37 & $(0.0019)$ & 0.27 & $(0.0019)$ \\
\hline & Less than primary & 0.16 & $(0.0014)$ & 0.14 & $(0.0014)$ & 0.11 & $(0.0014)$ \\
\hline & Primary & 0.15 & $(0.0014)$ & 0.13 & $(0.0013)$ & 0.15 & $(0.0015)$ \\
\hline & Middle & 0.12 & $(0.0012)$ & 0.16 & $(0.0014)$ & 0.19 & $(0.0017)$ \\
\hline & Secondary - High Secondary & 0.10 & $(0.0011)$ & 0.16 & $(0.0014)$ & 0.21 & $(0.0017)$ \\
\hline & Graduate and above & 0.03 & $(0.0006)$ & 0.05 & $(0.0009)$ & 0.07 & $(0.0011)$ \\
\hline Household size & Log household size & 1.72 & $(0.0017)$ & 1.69 & $(0.0018)$ & 1.59 & $(0.0019)$ \\
\hline Male members & Percentage male adults & 0.48 & $(0.0006)$ & 0.48 & $(0.0006)$ & 0.49 & $(0.0006)$ \\
\hline $\begin{array}{l}\text { Children in } \\
\text { household }\end{array}$ & Share of children under 5 & 0.15 & $(0.0006)$ & 0.13 & $(0.0006)$ & 0.1 & $(0.0006)$ \\
\hline \multirow{3}{*}{$\begin{array}{l}\text { Household's } \\
\text { social group }\end{array}$} & Scheduled Caste (SC) & 0.18 & $(0.0014)$ & 0.21 & $(0.0016)$ & 0.21 & $(0.0017)$ \\
\hline & Scheduled Tribe (ST) & 0.10 & $(0.0011)$ & 0.10 & $(0.0012)$ & 0.10 & $(0.0013)$ \\
\hline & Others & 0.71 & $(0.0017)$ & 0.69 & $(0.0018)$ & 0.69 & $(0.0019)$ \\
\hline \multirow[t]{4}{*}{ Religion } & Hindu & 0.85 & $(0.0013)$ & 0.85 & $(0.0014)$ & 0.85 & $(0.0015)$ \\
\hline & Muslim & 0.10 & $(0.0011)$ & 0.10 & $(0.0011)$ & 0.10 & $(0.0013)$ \\
\hline & Christian & 0.02 & $(0.0005)$ & 0.02 & $(0.0006)$ & 0.02 & $(0.0006)$ \\
\hline & Others & 0.03 & $(0.0007)$ & 0.03 & $(0.0007)$ & 0.03 & $(0.0007)$ \\
\hline
\end{tabular}

Source: NSS (1987, 1999, 2009) Employment and Unemployment Schedule (Authors' calculations).

Note: The sample includes 25-65 years old, rural married women. The descriptive statistics have been estimated using sampling weights provided in the NSS. The cut-offs for income deciles for the year 1987 are used and adjusted for cost of living for 1999 and 2009. 
Table 2: Blinder-Oaxaca Decomposition of Change in Women's LFPR

\begin{tabular}{|c|c|c|c|c|c|}
\hline & (1) & (2) & (3) & (4) & (5) \\
\hline \multicolumn{6}{|l|}{ Panel A: 1987-1999 } \\
\hline Change in predicted LFPR & 0.0310 & 0.0310 & 0.0310 & 0.0309 & 0.0331 \\
\hline \multicolumn{6}{|l|}{ Explained component at: } \\
\hline 1987 coefficients & 0.0210 & 0.0267 & 0.0322 & 0.0410 & 0.0449 \\
\hline 1999 coefficients & 0.0216 & 0.0322 & 0.0370 & 0.0433 & 0.0468 \\
\hline \multicolumn{6}{|l|}{ Explained proportion at: } \\
\hline 1987 coefficients & 0.68 & 0.86 & 1.04 & 1.33 & 1.36 \\
\hline 1999 coefficients & 0.70 & 1.04 & 1.20 & 1.40 & 1.41 \\
\hline \multicolumn{6}{|l|}{ Panel B: 1999-2009 } \\
\hline Change in predicted LFPR & 0.0896 & 0.0896 & 0.0896 & 0.0924 & 0.0924 \\
\hline \multicolumn{6}{|l|}{ Explained component at: } \\
\hline 1999 coefficients & 0.0300 & 0.0319 & 0.0415 & 0.0385 & 0.0460 \\
\hline 2009 coefficients & 0.0150 & 0.0172 & 0.0152 & 0.0203 & 0.0172 \\
\hline \multicolumn{6}{|l|}{ Explained proportion at: } \\
\hline 1999 coefficients & 0.33 & 0.36 & 0.46 & 0.42 & 0.50 \\
\hline 2009 coefficients & 0.17 & 0.19 & 0.17 & 0.22 & 0.19 \\
\hline \multicolumn{6}{|l|}{ Controls included: } \\
\hline Own age group & Yes & Yes & Yes & Yes & Yes \\
\hline Own education & Yes & Yes & Yes & Yes & Yes \\
\hline Land ownership & & Yes & Yes & Yes & Yes \\
\hline Household income & & & Yes & & Yes \\
\hline Max. male education & & & & Yes & Yes \\
\hline
\end{tabular}

Note: A woman is defined to be in labor force if she is working or seeking work as her primary or subsidiary activity. LFPR is the share of women in the labor force. The sample includes rural married women aged 25-65. The analysis incorporates the sampling weights in NSS. Explained proportion is calculated by dividing the explained component by the change in predicted LFPR (e.g. in the first column: $0.0210 / 0.0310=0.68$ ). Because our decomposition subtracts 1999 from 1987 (or 2009 from 1999), and female LFPR are falling over time, the changes in LFPR are positive. 
Table 3: DFL Decomposition of Change in Women's LFPR

\begin{tabular}{|c|c|c|c|c|c|c|}
\hline & (1) & (2) & (3) & (4) & (5) & (6) \\
\hline \multicolumn{7}{|l|}{ Panel A: 1987-1999 } \\
\hline Change in predicted LFPR & 0.0311 & 0.0311 & 0.0311 & 0.0311 & 0.0311 & 0.0311 \\
\hline \multicolumn{7}{|l|}{ Explained proportion at: } \\
\hline 1987 coefficients & 0.67 & 0.83 & 0.97 & 1.33 & 1.41 & 1.31 \\
\hline 1999 coefficients & 0.69 & 1.05 & 1.16 & 1.39 & 1.46 & 1.45 \\
\hline \multicolumn{7}{|l|}{ Panel B: 1999-2009 } \\
\hline Change in predicted LFPR & 0.0897 & 0.0897 & 0.0897 & 0.0897 & 0.0897 & 0.0897 \\
\hline \multicolumn{7}{|l|}{ Explained proportion at: } \\
\hline 1999 coefficients & 0.34 & 0.36 & 0.47 & 0.44 & 0.53 & 0.53 \\
\hline 2009 coefficients & 0.16 & 0.19 & 0.16 & 0.18 & 0.14 & 0.13 \\
\hline \multicolumn{7}{|l|}{ Controls included: } \\
\hline Own age group & Yes & Yes & Yes & Yes & Yes & Yes \\
\hline Own education & Yes & Yes & Yes & Yes & Yes & Yes \\
\hline Land ownership & & Yes & Yes & Yes & Yes & Yes \\
\hline Household income & & & Yes & & Yes & Yes \\
\hline Max. male education & & & & Yes & Yes & Yes \\
\hline All two-way interactions & & & & & & Yes \\
\hline
\end{tabular}

Note: A woman is defined to be in the labor force if she is working or seeking work as her primary or subsidiary activity. LFPR is the share of women in the labor force. The sample includes rural married women aged 25-65. The analysis incorporates the sampling weights in NSS. The specification in column (6) includes two-way interactions between all the variables when estimating the re-weighting function. See the Methodology section for an explanation of the non-parametric DFL (Dinardo-Fortin-Lemieux) decomposition technique. Because our decomposition subtracts 1999 from 1987 (or 2009 from 1999), and female LFPR are falling over time, the changes in LFPR are positive. 
Table 4: Relative Contributions of Characteristics to Blinder-Oaxaca Decomposition of Change in Women's LFPR

\begin{tabular}{|c|c|c|c|c|c|c|c|c|c|c|}
\hline $\begin{array}{l}\text { Contribution to } \\
\text { explained variation }\end{array}$ & (1) & & $(2)$ & & (3) & & (4) & & (5) & \\
\hline Panel A: 1987-1999 & & & & & & & & & & \\
\hline 1987 coefficients & & & & & & & & & & \\
\hline Explained proportion & 0.68 & & 0.86 & & 1.04 & & 1.33 & & 1.36 & \\
\hline Own age group & -0.02 & & 0.00 & & 0.00 & & -0.01 & & -0.01 & \\
\hline & -0.0003 & $* *$ & 0.0000 & & 0.0000 & & -0.0005 & $* * *$ & -0.0005 & $* * *$ \\
\hline & $(0.0001)$ & & $(0.0001)$ & & $(0.0001)$ & & $(0.0001)$ & & $(0.0001)$ & \\
\hline Own education & 1.02 & & 0.81 & & 0.58 & & 0.22 & & 0.16 & \\
\hline & 0.0213 & $* * *$ & 0.0216 & $* * *$ & 0.0186 & $* * *$ & 0.0088 & $* * *$ & 0.0072 & $* * *$ \\
\hline & $(0.0008)$ & & $(0.0008)$ & & $(0.0008)$ & & $(0.0009)$ & & $(0.0009)$ & \\
\hline Household's land & & & & & & & & & & \\
\hline ownership & & & 0.19 & & 0.22 & & 0.17 & & 0.19 & \\
\hline & & & 0.0052 & $* * *$ & 0.0071 & $* * *$ & 0.0071 & $* * *$ & 0.0085 & $* * *$ \\
\hline & & & $(0.0004)$ & & $(0.0004)$ & & $(0.0004)$ & & $(0.0004)$ & \\
\hline Household income & & & & & 0.21 & & & & 0.12 & \\
\hline & & & & & 0.0066 & $* * *$ & & & 0.0052 & $* * *$ \\
\hline & & & & & $(0.0004)$ & & & & $(0.0004)$ & \\
\hline $\begin{array}{l}\text { Household's male } \\
\text { education }\end{array}$ & & & & & & & 0.62 & & 0.54 & \\
\hline & & & & & & & 0.0255 & $* * *$ & 0.0244 & $* * *$ \\
\hline & & & & & & & $(0.0008)$ & & $(0.0008)$ & \\
\hline 1999 coefficients & & & & & & & & & & \\
\hline Explained proportion & 0.70 & & 1.04 & & 1.20 & & 1.40 & & 1.41 & \\
\hline Own age group & -0.02 & & 0.00 & & 0.01 & & $\mathbf{0 . 0 0}$ & & 0.00 & \\
\hline & -0.0005 & $* * *$ & 0.0001 & & 0.0003 & $* * *$ & 0.0000 & & -0.0001 & \\
\hline & $(0.0002)$ & & $(0.0001)$ & & $(0.0001)$ & & $(0.0001)$ & & $(0.0001)$ & \\
\hline Own education & 1.02 & & 0.70 & & 0.50 & & 0.31 & & 0.24 & \\
\hline & 0.0220 & $* * *$ & 0.0224 & $* * *$ & 0.0187 & $* * *$ & 0.0132 & $* * *$ & 0.0111 & $* * *$ \\
\hline & $(0.0007)$ & & $(0.0007)$ & & $(0.0007)$ & & $(0.0008)$ & & $(0.0008)$ & \\
\hline Household's land & & & & & & & & & & \\
\hline ownership & & & 0.30 & & 0.34 & & 0.25 & & 0.28 & \\
\hline & & & 0.0096 & $* * *$ & 0.0124 & $* * *$ & 0.0109 & $* * *$ & 0.0134 & $* * *$ \\
\hline & & & $(0.0005)$ & & $(0.0004)$ & & $(0.0005)$ & & $(0.0005)$ & \\
\hline Household income & & & & & 0.15 & & & & 0.10 & \\
\hline & & & & & 0.0055 & $* * *$ & & & 0.0046 & $* * *$ \\
\hline & & & & & $(0.0004)$ & & & & $(0.0005)$ & \\
\hline $\begin{array}{l}\text { Household's male } \\
\text { education }\end{array}$ & & & & & & & 0.44 & & 0.38 & \\
\hline & & & & & & & 0.0191 & $* * *$ & 0.0180 & $* * *$ \\
\hline & & & & & & & $(0.0008)$ & & $(0.0008)$ & \\
\hline
\end{tabular}


Table 4: Relative Contributions of Characteristics to Blinder-Oaxaca Decomposition of Change in Women's LFPR (continued)

\begin{tabular}{|c|c|c|c|c|c|c|c|c|c|c|}
\hline \multirow{2}{*}{$\begin{array}{l}\begin{array}{l}\text { Contribution to } \\
\text { explained variation }\end{array} \\
\text { Panel B: } 1999-2009\end{array}$} & \multicolumn{2}{|l|}{ (1) } & \multicolumn{2}{|l|}{ (2) } & \multicolumn{2}{|l|}{ (3) } & \multicolumn{2}{|l|}{ (4) } & \multicolumn{2}{|l|}{ (5) } \\
\hline & & & & & & & & & & \\
\hline \multicolumn{11}{|l|}{1999 coefficients } \\
\hline Explained proportion & 0.33 & & 0.36 & & 0.46 & & 0.42 & & 0.50 & \\
\hline \multirow[t]{3}{*}{ Own age group } & -0.01 & & -0.01 & & 0.00 & & -0.01 & & -0.02 & \\
\hline & -0.0003 & & -0.0002 & & -0.0001 & & -0.0004 & $* *$ & -0.0008 & $* * *$ \\
\hline & $(0.0002)$ & & $(0.0002)$ & & $(0.0002)$ & & $(0.0002)$ & & $(0.0002)$ & \\
\hline \multirow[t]{3}{*}{ Own education } & 1.01 & & 0.99 & & 0.62 & & 0.47 & & 0.32 & \\
\hline & 0.0304 & $* * *$ & 0.0315 & $* * *$ & 0.0256 & $* * *$ & 0.0180 & $* * *$ & 0.0146 & $* * *$ \\
\hline & $(0.001)$ & & $(0.001)$ & & $(0.001)$ & & $(0.0012)$ & & $(0.0012)$ & \\
\hline \multirow[t]{3}{*}{$\begin{array}{l}\text { Household's land } \\
\text { ownership }\end{array}$} & & & 0.02 & & 0.02 & & 0.01 & & 0.02 & \\
\hline & & & 0.0005 & $* * *$ & 0.0010 & $* * *$ & 0.0003 & $* *$ & 0.0008 & $* * *$ \\
\hline & & & $(0.0002)$ & & $(0.0002)$ & & $(0.0001)$ & & $(0.0001)$ & \\
\hline \multirow[t]{3}{*}{ Household income } & & & & & 0.36 & & & & 0.27 & \\
\hline & & & & & 0.0151 & $* * *$ & & & 0.0122 & $* * *$ \\
\hline & & & & & $(0.0011)$ & & & & $(0.0011)$ & \\
\hline \multirow[t]{3}{*}{$\begin{array}{l}\text { Household's male } \\
\text { education }\end{array}$} & & & & & & & 0.53 & & 0.42 & \\
\hline & & & & & & & 0.0206 & $* * *$ & 0.0191 & $* * *$ \\
\hline & & & & & & & $(0.0009)$ & & $(0.0009)$ & \\
\hline \multicolumn{11}{|l|}{2009 coefficients } \\
\hline Explained proportion & 0.17 & & 0.19 & & 0.17 & & 0.22 & & 0.19 & \\
\hline \multirow[t]{3}{*}{ Own age group } & -0.08 & & -0.07 & & -0.05 & & -0.06 & & -0.07 & \\
\hline & -0.0011 & $* * *$ & -0.0012 & $* * *$ & -0.0008 & $* * *$ & -0.0013 & $* * *$ & -0.0012 & $* * *$ \\
\hline & $(0.0003)$ & & $(0.0003)$ & & $(0.0003)$ & & $(0.0003)$ & & $(0.0003)$ & \\
\hline \multirow[t]{3}{*}{ Own education } & 1.08 & & 1.00 & & 1.15 & & 0.45 & & 0.59 & \\
\hline & 0.0162 & $* * *$ & 0.0171 & $* * *$ & 0.0174 & $* * *$ & 0.0091 & $* * *$ & 0.0102 & $* * *$ \\
\hline & $(0.0013)$ & & $(0.0013)$ & & $(0.0013)$ & & $(0.0016)$ & & $(0.0016)$ & \\
\hline \multirow{4}{*}{$\begin{array}{l}\text { Household's land } \\
\text { ownership }\end{array}$} & & & & & & & & & & \\
\hline & & & 0.07 & & 0.09 & & 0.02 & & 0.03 & \\
\hline & & & 0.0012 & $* * *$ & 0.0013 & $* * *$ & 0.0003 & & 0.0005 & $* *$ \\
\hline & & & $(0.0003)$ & & $(0.0003)$ & & $(0.0002)$ & & $(0.0002)$ & \\
\hline \multirow[t]{3}{*}{ Household income } & & & & & -0.18 & & & & -0.28 & \\
\hline & & & & & -0.0027 & $*$ & & & -0.0047 & $* * *$ \\
\hline & & & & & $(0.0015)$ & & & & $(0.0017)$ & \\
\hline \multirow[t]{3}{*}{$\begin{array}{l}\text { Household's male } \\
\text { education }\end{array}$} & & & & & & & 0.60 & & 0.73 & \\
\hline & & & & & & & 0.0121 & $* * *$ & 0.0125 & $* * *$ \\
\hline & & & & & & & $(0.0015)$ & & $(0.0015)$ & \\
\hline
\end{tabular}

Note: The bold figures reflect the proportion of contribution of a characteristic to the explained component of the decomposition. It is estimated by dividing the component explained by the characteristic (below the bold figures) by the explained component for that specification in Table 2. Rounding off errors. Standard errors in parenthesis. $* * *, * *, *$ significant at $1 \%, 5 \%$ and $10 \%$, respectively. 
Table 5. Blinder-Oaxaca Decomposition of Changes in Female Domestic Work Participation

\begin{tabular}{|c|c|c|c|c|c|c|c|c|}
\hline \multirow[b]{3}{*}{ Change in predicted domestic work } & \multicolumn{3}{|c|}{ 1987-1999 } & \multicolumn{5}{|c|}{ 1999-2009 } \\
\hline & \multicolumn{2}{|l|}{ (1) } & \multicolumn{2}{|l|}{ (2) } & \multicolumn{2}{|l|}{ (3) } & \multicolumn{2}{|l|}{ (4) } \\
\hline & \multicolumn{2}{|l|}{-0.0300} & -0.0300 & & \multicolumn{2}{|l|}{-0.0705} & \multicolumn{2}{|l|}{-0.0735} \\
\hline Panel A & \multicolumn{3}{|c|}{1987 coefficients } & \multicolumn{5}{|c|}{1999 coefficients } \\
\hline Explained proportion & 1.07 & & 1.45 & & 0.6 & & 0.64 & \\
\hline Explained component & -0.0320 & & -0.0434 & & -0.0422 & & -0.0470 & \\
\hline \multicolumn{9}{|l|}{ Variables } \\
\hline \multirow[t]{2}{*}{ Own age group } & -0.01 & & -0.01 & & -0.03 & & -0.03 & \\
\hline & $\begin{array}{r}0.0004 \\
(0.0001)\end{array}$ & $* * *$ & $\begin{array}{r}0.0004 \\
(0.0001)\end{array}$ & $* * *$ & $\begin{array}{r}0.0013 \\
(0.0002)\end{array}$ & $* * *$ & $\begin{array}{r}0.0014 \\
(0.0002)\end{array}$ & $* * *$ \\
\hline \multirow[t]{2}{*}{ Own education } & 0.45 & & 0.11 & & 0.38 & & 0.13 & \\
\hline & $\begin{array}{r}-0.0143 \\
(0.0007)\end{array}$ & $* * *$ & $\begin{array}{r}-0.0050 \\
(0.0008)\end{array}$ & $* * *$ & $\begin{array}{r}-0.0158 \\
(0.0009)\end{array}$ & $* * *$ & $\begin{array}{r}-0.0063 \\
(0.0011)\end{array}$ & $* * *$ \\
\hline \multirow[t]{2}{*}{ Household's land ownership } & 0.26 & & 0.21 & & 0.01 & & -0.01 & \\
\hline & $\begin{array}{r}-0.0082 \\
(0.0005)\end{array}$ & $* * *$ & $\begin{array}{r}-0.0091 \\
(0.0004)\end{array}$ & $* * *$ & $\begin{array}{r}-0.000 \\
(0.0001)\end{array}$ & $* *$ & $\begin{array}{r}0.0007 \\
(0.0001)\end{array}$ & $* * *$ \\
\hline \multirow[t]{2}{*}{ Household income } & 0.31 & & 0.17 & & 0.65 & & 0.49 & \\
\hline & $\begin{array}{c}-0.0099 \\
(0.0005)\end{array}$ & $* * *$ & $\begin{array}{r}-0.0074 \\
(0.0004)\end{array}$ & $* * *$ & $\begin{array}{r}-0.0275 \\
(0.0011)\end{array}$ & $* * *$ & $\begin{array}{r}-0.0233 \\
(0.0011)\end{array}$ & $* * *$ \\
\hline \multirow[t]{2}{*}{ Household's male education } & & & 0.52 & & & & 0.42 & \\
\hline & & & $\begin{array}{r}-0.0224 \\
(0.0008)\end{array}$ & $* * *$ & & & $\begin{array}{r}-0.0196 \\
(0.0009)\end{array}$ & $* * *$ \\
\hline Panel B & \multicolumn{3}{|c|}{1999 coefficients } & & \multicolumn{3}{|c|}{2009 coefficients } & \\
\hline Explained proportion & 1.1 & & 1.42 & & 0.19 & & 0.21 & \\
\hline Explained component & -0.0329 & & -0.0426 & & -0.0131 & & -0.0152 & \\
\hline \multicolumn{9}{|l|}{ Variables } \\
\hline \multirow[t]{2}{*}{ Own age group } & -0.02 & & -0.01 & & -0.18 & & -0.19 & \\
\hline & $\begin{array}{r}0.0006 \\
(0.0002)\end{array}$ & $* * *$ & $\begin{array}{r}0.0006 \\
(0.0002)\end{array}$ & $* * *$ & $\begin{array}{r}0.0024 \\
(0.0004)\end{array}$ & $* * *$ & $\begin{array}{r}0.0028 \\
(0.0005)\end{array}$ & $* * *$ \\
\hline \multirow[t]{3}{*}{ Own education } & 0.36 & & 0.14 & & 0.67 & & 0.18 & \\
\hline & -0.0120 & $* * *$ & -0.0058 & $* * *$ & -0.0087 & $* * *$ & -0.0027 & $* *$ \\
\hline & $(0.0006)$ & & $(0.0007)$ & & $(0.0012)$ & & $(0.0015)$ & \\
\hline \multirow[t]{3}{*}{ Household's land ownership } & 0.30 & & 0.25 & & 0.07 & & -0.01 & \\
\hline & -0.0098 & $* * *$ & -0.0105 & $* * *$ & -0.0008 & $* * *$ & 0.0002 & \\
\hline & $(0.0005)$ & & $(0.0005)$ & & $(0.0003)$ & & $(0.0003)$ & \\
\hline \multirow[t]{2}{*}{ Household income } & 0.36 & & 0.21 & & 0.45 & & 0.29 & \\
\hline & $\begin{array}{r}-0.0117 \\
(0.0006)\end{array}$ & $* * *$ & $\begin{array}{r}-0.0090 \\
(0.0006)\end{array}$ & $* * *$ & $\begin{array}{l}-0.0059 \\
(0.0016)\end{array}$ & $* * *$ & $\begin{array}{r}-0.0045 \\
(0.0017)\end{array}$ & $* * *$ \\
\hline \multirow[t]{2}{*}{ Household's male education } & & & 0.42 & & & & 0.72 & \\
\hline & & & $\begin{array}{r}-0.0179 \\
(0.0008)\end{array}$ & $* * *$ & & & $\begin{array}{c}-0.0109 \\
(0.0016)\end{array}$ & $* * *$ \\
\hline
\end{tabular}

Note: The dependent variable is a dichotomous variable: a woman is engaged in domestic work if her primary status during the last year was domestic work. The sample includes rural married women aged 25-65. The analysis incorporates the sampling weights in NSS. The explained proportion is the explained component divided by the change in predicted domestic work. Figures in bold are the shares of the overall predicted variation accounted for by a specific characteristic and are estimated by dividing the component explained by the characteristic (below the bold figures) by the explained component for that specification. Standard errors in parenthesis. $* * *, * *, *$ significant at $1 \%, 5 \%$ and $10 \%$, respectively. 


\section{Appendices}

\section{Appendix A. Definition of Labor Force Participation Rates}

The National Sample Survey uses three reference periods for the employment survey (i) one year, (ii) one week and (iii) each day of the previous week. This paper employs the Usual Principal and Subsidiary Status (UPSS) definition. The activity status on which a person spent relatively longer time (major time criterion) during the 365 days preceding the date of survey is considered the Usual Principal Activity Status of the person. Persons are first categorized as those in the labor force and those out of the labor force depending on the major time spent during the 365 days preceding the date of survey. For persons belonging to the labor force, the broad activity status of either 'working' (employed) or 'not working but seeking and/or available for work' (unemployed) is then ascertained based on the time criterion. After determining the principal status, the economic activity on which a person spent 30 days or more during the reference period of 365 days preceding the date of survey is recorded as the Subsidiary Economic Activity Status of a person. In case of multiple subsidiary economic activities, the major activity and status based on the relatively longer time spent criterion is considered. If a person is defined to be in the labor force in either the principal activity status or the subsidiary activity status then she is defined to be in the labor force according to the UPSS. A woman who reports her primary activity is domestic production is classified as out of the labor force. 


\section{Appendix B. Robustness Checks}

Table B.1. Blinder-Oaxaca Decomposition for Change in Women's LFPR and Change in Domestic Work with Additional Controls

\begin{tabular}{|c|c|c|c|c|c|c|c|c|}
\hline \multirow{3}{*}{$\begin{array}{l}\text { Change during } \\
\text { Difference in predicted } \\
\text { LFPR }\end{array}$} & \multicolumn{3}{|c|}{ Women's LFPR } & \multicolumn{5}{|c|}{ Women's Domestic work } \\
\hline & 1987-1999 & & 1999-2009 & & 1987-1999 & & 1999-2009 & \\
\hline & 0.0331 & & 0.0923 & & -0.0300 & & -0.0735 & \\
\hline Coefficient & 1987 & & 1999 & & 1987 & & 1999 & \\
\hline Explained proportion & 1.06 & & 0.40 & & 1.16 & & 0.48 & \\
\hline $\begin{array}{l}\text { Explained component } \\
\text { Variables }\end{array}$ & 0.0352 & & 0.0365 & & -0.0347 & & -0.0353 & \\
\hline Own age group & $\begin{array}{r}-0.02 \\
-0.0007 \\
(0.0001)\end{array}$ & $* * *$ & $\begin{array}{r}-0.02 \\
-0.0008 \\
(0.0002)\end{array}$ & $* * *$ & $\begin{array}{r}-0.01 \\
0.0004 \\
(0.0001)\end{array}$ & $* * *$ & $\begin{array}{r}-0.03 \\
0.0010 \\
(0.0001)\end{array}$ & $* * *$ \\
\hline Own education & $\begin{array}{r}\mathbf{0 . 2 5} \\
0.0088 \\
(0.0009)\end{array}$ & $* * *$ & $\begin{array}{r}\mathbf{0 . 4 1} \\
0.0150 \\
(0.0012)\end{array}$ & $* * *$ & $\begin{array}{r}\mathbf{0 . 1 9} \\
-0.0067 \\
(0.0008)\end{array}$ & $* * *$ & $\begin{array}{r}\mathbf{0 . 2 4} \\
-0.0085 \\
(0.0008)\end{array}$ & $* * *$ \\
\hline $\begin{array}{l}\text { Household's land } \\
\text { ownership }\end{array}$ & $\begin{array}{r}0.23 \\
0.0081 \\
(0.0005)\end{array}$ & $* * *$ & $\begin{array}{r}0.04 \\
0.0015 \\
(0.0001)\end{array}$ & $* * *$ & $\begin{array}{r}0.23 \\
-0.0082 \\
(0.0004)\end{array}$ & $* * *$ & $\begin{array}{r}0.00 \\
0.0001 \\
(0.0004)\end{array}$ & \\
\hline Household income & $\begin{array}{r}0.14 \\
0.0048 \\
(0.0004)\end{array}$ & $* * *$ & $\begin{array}{r}0.34 \\
0.0125 \\
(0.0011)\end{array}$ & $* * *$ & $\begin{array}{r}0.19 \\
-0.0066 \\
(0.0004)\end{array}$ & $* * *$ & $\begin{array}{r}0.67 \\
-0.0236 \\
(0.0004)\end{array}$ & $* * *$ \\
\hline $\begin{array}{l}\text { Household's male } \\
\text { education }\end{array}$ & 0.48 & & 0.34 & & 0.40 & & 0.31 & \\
\hline & $\begin{array}{r}0.0168 \\
(0.0007)\end{array}$ & $* * *$ & $\begin{array}{r}0.0123 \\
(0.0008)\end{array}$ & $* * *$ & $\begin{array}{r}-0.0139 \\
(0.0007)\end{array}$ & $* * *$ & $\begin{array}{r}-0.0111 \\
(0.0007)\end{array}$ & $* * *$ \\
\hline Social group & $\begin{array}{r}-0.08 \\
-0.0028 \\
(0.0002)\end{array}$ & $* * *$ & $\begin{array}{r}-0.05 \\
-0.0018 \\
(0.0001)\end{array}$ & $* * *$ & $\begin{array}{r}-0.04 \\
0.0012 \\
(0.0001)\end{array}$ & $* * *$ & $\begin{array}{r}-0.01 \\
0.0002 \\
(0.0001)\end{array}$ & $* *$ \\
\hline Religion & $\begin{array}{r}0.08 \\
0.0027 \\
(0.0002)\end{array}$ & $* * *$ & $\begin{array}{r}0.17 \\
0.0060 \\
(0.0004)\end{array}$ & $* * *$ & $\begin{array}{r}0.16 \\
-0.0054 \\
(0.0003)\end{array}$ & $* * *$ & $\begin{array}{r}0.18 \\
-0.0063 \\
(0.0003)\end{array}$ & $* * *$ \\
\hline Percentage male adults & $\begin{array}{r}0.01 \\
0.0005 \\
(0.0000)\end{array}$ & $* * *$ & $\begin{array}{r}0.01 \\
0.0005 \\
(0.0001)\end{array}$ & $* * *$ & $\begin{array}{r}-0.01 \\
0.0002 \\
(0.0000)\end{array}$ & $* * *$ & $\begin{array}{r}-0.01 \\
0.0004 \\
(0.0000)\end{array}$ & $* * *$ \\
\hline Share of children under 5 & $\begin{array}{r}-0.02 \\
-0.0008 \\
(0.0003)\end{array}$ & $* *$ & $\begin{array}{r}-0.05 \\
-0.0020 \\
(0.0006)\end{array}$ & $* * *$ & $\begin{array}{r}-0.05 \\
0.0017 \\
(0.0003)\end{array}$ & $* * *$ & $\begin{array}{r}-0.13 \\
0.0047 \\
(0.0003)\end{array}$ & $* * *$ \\
\hline Household size & $\begin{array}{r}-0.06 \\
-0.0023 \\
(0.0001)\end{array}$ & $* * *$ & $\begin{array}{r}-0.19 \\
-0.0068 \\
(0.0006)\end{array}$ & $* * *$ & $\begin{array}{r}-0.07 \\
0.0025 \\
(0.0002)\end{array}$ & $* * *$ & $\begin{array}{r}-0.22 \\
0.0077 \\
(0.0002)\end{array}$ & $* * *$ \\
\hline
\end{tabular}


Table B.1. Blinder-Oaxaca Decomposition for Change in Women's LFPR and Change in Domestic Work with Additional Controls (continued)

\begin{tabular}{|c|c|c|c|c|c|c|c|c|}
\hline \multirow{3}{*}{$\begin{array}{l}\text { Change during } \\
\text { Difference in predicted } \\
\text { LFPR }\end{array}$} & \multicolumn{3}{|c|}{ Women's LFPR } & \multicolumn{5}{|c|}{ Women's Domestic work } \\
\hline & 1987-1999 & & 1999-2009 & & $\begin{array}{r}1987- \\
1999\end{array}$ & & $\begin{array}{r}1999- \\
2009\end{array}$ & \\
\hline & 0.0331 & & 0.0923 & & -0.0300 & & -0.0735 & \\
\hline Coefficient & 1987 & & 1999 & & 1987 & & 1999 & \\
\hline Explained proportion & 1.10 & & 0.16 & & 1.03 & & 0.13 & \\
\hline $\begin{array}{l}\text { Explained component } \\
\text { Variables }\end{array}$ & 0.0364 & & 0.0145 & & -0.0308 & & -0.0097 & \\
\hline Own age group & -0.01 & & -0.09 & & -0.01 & & -0.24 & \\
\hline & $\begin{array}{r}-0.0005 \\
(0.0001)\end{array}$ & $* * *$ & $\begin{array}{r}-0.0012 \\
(0.0003)\end{array}$ & $* * *$ & $\begin{array}{r}0.0004 \\
(0.0002)\end{array}$ & $* *$ & $\begin{array}{r}0.0024 \\
(0.0004)\end{array}$ & $* * *$ \\
\hline Own education & $\begin{array}{r}\mathbf{0 . 3 0} \\
0.0110 \\
(0.0008)\end{array}$ & $* * *$ & $\begin{array}{r}\mathbf{0 . 7 6} \\
0.0110 \\
(0.0016)\end{array}$ & $* * *$ & $\begin{array}{r}0.22 \\
-0.0068 \\
(0.0007)\end{array}$ & $* * *$ & $\begin{array}{r}0.45 \\
-0.0044 \\
(0.0015)\end{array}$ & $* * *$ \\
\hline $\begin{array}{l}\text { Household's land } \\
\text { ownership }\end{array}$ & $\begin{array}{r}0.33 \\
0.0121 \\
(0.0006)\end{array}$ & $* * *$ & $\begin{array}{r}0.04 \\
0.0006 \\
(0.0002)\end{array}$ & $* * *$ & $\begin{array}{r}0.28 \\
-0.0086 \\
(0.0005)\end{array}$ & $* * *$ & $\begin{array}{r}0.00 \\
0.0000 \\
(0.0002)\end{array}$ & \\
\hline Household income & $\begin{array}{r}0.11 \\
0.0039 \\
(0.0005)\end{array}$ & $* * *$ & $\begin{array}{r}-0.40 \\
-0.0058 \\
(0.0017)\end{array}$ & $* * *$ & $\begin{array}{r}0.27 \\
-0.0083 \\
(0.0006)\end{array}$ & $* * *$ & $\begin{array}{r}0.32 \\
-0.0032 \\
(0.0018)\end{array}$ & $*$ \\
\hline $\begin{array}{l}\text { Household's male } \\
\text { education }\end{array}$ & 0.33 & & 0.60 & & 0.34 & & 0.69 & \\
\hline & $\begin{array}{r}0.0121 \\
(0.0007)\end{array}$ & $* * *$ & $\begin{array}{r}0.0087 \\
(0.0014)\end{array}$ & $* * *$ & $\begin{array}{r}-0.0105 \\
(0.0007)\end{array}$ & $* * *$ & $\begin{array}{r}-0.0068 \\
(0.0014)\end{array}$ & $* * *$ \\
\hline Social group & $\begin{array}{r}-0.09 \\
-0.0035 \\
(0.0002)\end{array}$ & $* * *$ & $\begin{array}{r}-0.02 \\
-0.0002 \\
(0.0001)\end{array}$ & $* *$ & $\begin{array}{r}-0.06 \\
0.0020 \\
(0.0002)\end{array}$ & $* * *$ & $\begin{array}{r}0.03 \\
-0.0003 \\
(0.0001)\end{array}$ & $* * *$ \\
\hline Religion & $\begin{array}{r}0.11 \\
0.0039 \\
(0.0003)\end{array}$ & $* * *$ & $\begin{array}{r}0.37 \\
0.0054 \\
(0.0004)\end{array}$ & $* * *$ & $\begin{array}{r}0.15 \\
-0.0048 \\
(0.0003)\end{array}$ & $* * *$ & $\begin{array}{r}0.48 \\
-0.0047 \\
(0.0003)\end{array}$ & $* * *$ \\
\hline Percentage male adults & $\begin{array}{r}0.01 \\
0.0005 \\
(0.0001)\end{array}$ & $* * *$ & $\begin{array}{r}0.00 \\
0.0000 \\
(0.0001)\end{array}$ & & $\begin{array}{r}0.00 \\
0.0001 \\
(0.0000)\end{array}$ & $* * *$ & $\begin{array}{r}-0.10 \\
0.0010 \\
(0.0001)\end{array}$ & $* * *$ \\
\hline Share of children under 5 & $\begin{array}{r}-0.03 \\
-0.0013 \\
(0.0004)\end{array}$ & $* * *$ & $\begin{array}{r}-0.05 \\
-0.0007 \\
(0.001)\end{array}$ & & $\begin{array}{r}-0.10 \\
0.0031 \\
(0.0004)\end{array}$ & $* * *$ & $\begin{array}{r}-0.17 \\
0.0017 \\
(0.0009)\end{array}$ & $*$ \\
\hline Household size & $\begin{array}{r}-0.05 \\
-0.0018 \\
(0.0002)\end{array}$ & $* * *$ & $\begin{array}{r}-0.22 \\
-0.0032 \\
(0.0011)\end{array}$ & $* * *$ & $\begin{array}{r}-0.08 \\
0.0026 \\
(0.0002)\end{array}$ & $* * *$ & $\begin{array}{r}-0.46 \\
0.0045 \\
(0.0011)\end{array}$ & $* * *$ \\
\hline
\end{tabular}

Note: The first row against each characteristic in the above table reflects the proportion of contribution of a characteristic to the explained component of the decomposition. It is estimated by dividing the component explained by the characteristic (below the bold figures) by the explained component for that specification. Rounding off errors. Standard errors in parenthesis. ${ }^{* *},{ }^{* *}, *$ significant levels at $1 \%, 5 \%$ and $10 \%$, respectively. 